\title{
DEPOSITIONAL DEPTH OF LAMINATED CARBONATE DEPOSITS: INSIGHTS FROM THE LOWER CRETACEOUS VALDEPRADO FORMATION (CAMEROS BASIN, NORTHERN SPAIN)
}

\author{
I. EMMA QUIJADA, ${ }^{1,2}$ PABLO SUAREZ-GONZALEZ, ${ }^{1,2}$ M. ISABEL BENITO, ${ }^{1,2}$ AND RAMÓN MAS ${ }^{1,2}$ \\ ${ }^{1}$ Departamento de Estratigrafia, Universidad Complutense de Madrid, Cl José Antonio Novais 12, 28040 Madrid, Spain \\ ${ }^{2}$ Instituto de Geociencias IGEO (CSIC, UCM), Cl José Antonio Novais 12, 28040 Madrid, Spain \\ e-mail: equijada@geo.ucm.es
}

\begin{abstract}
The Lower Cretaceous (Berriasian) Valdeprado Formation (Cameros Basin, northern Spain) contains more than $900 \mathrm{~m}$ of laminated carbonates and pseudomorphs after sulfates. Traditionally, many sedimentary packages of different ages and lithologies have been interpreted as deep-water deposits based essentially on the abundance of laminations and the absence of subaerial exposure features. In contrast, the Valdeprado Formation provides an example of a shallow-water deposit dominated by laminations with scarce evidence of subaerial exposure, and gives criteria to solve the challenge of distinguishing shallow-water and deep-water, ancient laminated deposits.

The two most abundant facies all along the Valdeprado Formation are: a) parallel-laminated limestone, formed by alternating carbonate mudstone and calcite and quartz pseudomorphs after displacive gypsum, and b) graded-laminated limestone, consisting of quartz, mica, ostracodes, and pseudomorphs after detrital gypsum grains at the base, which changes gradually upwards to carbonate mudstone. Parallel-laminated limestone and graded-laminated limestone could have been deposited in either deep or shallow environments as a result of salinity fluctuations driven by alternation of flooding and evaporation and by sediment resuspension processes, respectively. Subaerial exposure features, such as desiccation mudcracks, are scarce in most of the succession, except in a few meter-scale stratigraphic intervals where they are very abundant. Interestingly, in these intervals desiccation cracks are present at the tops of several successive laminae (up to 25 mudcracked laminae per meter of deposit), indicating that, at least during those periods of time, deposition occurred in shallow water bodies that were desiccated frequently. In the upper part of the stratigraphic section, parallel-laminated and graded-laminated limestones are associated with current-ripple and wave-ripple cross-laminated arenites, and ostracode mudstone to wackestone with centimeter-size pseudomorphs after lenticular gypsum, and abundant desiccation mudcracks and tepees, which also suggest sedimentation in shallow-water environments. Moreover, the laminated carbonates display continuous, parallel layering, and the same facies along the 40-km-long outcropping area. These deposits are directly interbedded with, and pass laterally to, siliciclastic sandy-muddy flat deposits in the western area of the basin, without clinoforms, slump structures, or slide masses in between. All of these features suggest deposition in shallow, perennial carbonate-sulfate water bodies and their peripheral mudflats, developed in a flat-bottomed basin with no marked gradients.
\end{abstract}

\section{INTRODUCTION}

"Laminated lacustrine sediment forms where the lake bottom receives variable sediment input and retains conditions for the preservation of sediment with minimal disturbance or erosion" (Gierloswki-Kordesch 2010). These conditions for preservation are achieved where bottom current activity and burrowing are minimal or absent (Kelts and Hsü 1978; Anderson and Dean 1988; Glenn and Kelts 1991; Sabato et al. 2005; Pietras and Carroll 2006). Continental laminated carbonates can be deposited in deep and shallow sedimentary environments, as the requirements for preserving lamination may be fulfilled in both cases (e.g., Gierlowski-Kordesch 2010 and references therein; Renaut and Gierlowski-Kordesch 2010). Although the term "shallow lake has never been satisfactorily defined" (Thomas et al. 1996), several authors use the term "shallow" for lakes less than $10 \mathrm{~m}$ deep, inasmuch as this depth is generally the limit for light penetration and wind mixing of the water column (Kroes 1986; Smoot and Lowenstein 1991; Thomas et al. 1996;
Schubel and Lowenstein 1997). Accordingly, in this work the terms "shallow" and "deep" are used for depths of less and more than $\sim 10 \mathrm{~m}$, respectively. The factors that, individually or in combination, favor the preservation of laminae in lacustrine settings are meromixis of the water column (e.g., Kelts and Hsü 1978; Last and Vance 1997; Hakala 2004; Andrews et al. 2010; Zhang and Sha 2012), high and fluctuating salinity (e.g., Eugster and Hardie 1975; Smoot 1983; Smoot and Lowenstein 1991; Kendall 1992; Gierlowski-Kordesch and Rust 1994; Pietras and Carroll 2006), toxic compositions (Liutkus et al. 2010), warm temperatures, water stagnation, and a high rate of accumulation of organic debris (Buscalioni and Fregenal-Martínez 2010), microbial activity stabilizing the substrate (Finkelstein et al. 1999; Renaut and Gierlowski-Kordesch 2010), and high sedimentation rates (Kemp 1996). Despite the many examples of modern and ancient lacustrine laminated carbonates, interpretation of depositional depth of laminites in the stratigraphic record is still difficult. The presence of sedimentary features such as desiccation mudcracks (Eugster and Hardie 1975; Smoot 1983; Gierlowski-Kordesch and Rust 1994; 
Buscalioni and Fregenal-Martínez 2010), fossil biota characteristic of shallow conditions (Liutkus et al. 2010), or vertebrate footprints (Buscalioni and Fregenal-Martínez 2010) facilitate the recognition of shallow-water laminated carbonates; yet in the absence of these features, interpretation may be much more complicated, and carbonate laminites formed in shallow environments could be interpreted as deep deposits. In fact, several examples of laminated carbonates originally interpreted as deep-lake deposits have later been reinterpreted as representing shallow environments (e.g., Olsen 1986 and Fraser et al. 1996 vs. Liutkus et al. 2010).

The laminated deposits of the Lower Cretaceous (Berriasian) Valdeprado Formation from the Cameros Basin (northern Spain) consist of $900 \mathrm{~m}$ of alternating carbonate mudstone and calcite and quartz pseudomorphs after gypsum. The presence of pseudomorphs after gypsum in these facies suggests deposition in saline water bodies. Laminated deposits are common in perennial saline lakes, because high salinity excludes burrowing organisms and causes density stratification (e.g., Eugster and Hardie 1975; Smoot 1983; Smoot and Lowenstein 1991; Kendall 1992; Gierlowski-Kordesch and Rust 1994; Last and Vance 1997; Pietras and Carroll 2006; Liutkus et al. 2010). In deep areas of perennial saline lakes "settle-out sedimentation may produce fine, continuous laminae," whereas "in shallow water, settle-out deposits tend to have thicker, more irregular lamination or they are massive" (Smoot and Lowenstein 1991). In deep environments, cumulate crystal layers and gravity-flow deposits are the most common evaporitic facies (Smoot and Lowenstein 1991), although intrasediment evaporites (syndepositional evaporites that grow within unlithified sediment) may also be present (Warren 2006). In contrast, crusts and intrasediment evaporites predominate in shallow settings (Smoot and Lowenstein 1991).

The laminated carbonates of the Valdeprado Formation pose a sedimentological challenge, in that a number of their sedimentary features, common in the rock record, could have developed in either shallow-water or deep-water environments, and subaerial exposure evidence is scarce in a large part of the succession. The aim of the present study is to interpret the depositional depth of these laminated sediments, describing which sedimentary features are unsuitable for this purpose, and which criteria are considered diagnostic for recognition of laminated deposits formed under shallow-water conditions.

\section{METHODS}

Geological mapping of the Valdeprado Formation, including mapping of its limits and tectonic structures, has been performed using field observations, aerial photographs, and satellite images. Ten selected stratigraphic sections of the laminated carbonate deposits of the Valdeprado Formation in the eastern area of the Cameros Basin were studied: one complete stratigraphic section from the base to the top of the formation, where the succession shows the best outcropping conditions, and nine partial sections (Fig. 1). The stratigraphic sections were measured at the decimeter scale, and observations were taken at the centimeter and millimeter scale.

A total of 113 rock samples were collected for laboratory studies. For each sample, a polished and uncovered thin section was prepared to $30 \mu \mathrm{m}$ thickness for petrographic analysis under transmitted-light microscopy. A half of each thin section was stained with Alizarin Red S and potassium ferricyanide (Dickson 1966).

\section{GEOLOGIC SETTING}

The Valdeprado Formation is part of the sedimentary infill of the Cameros Basin (northern Spain) (Fig. 1), which is the northwesternmost basin of the Iberian Mesozoic Rift System (Mas et al. 1993; Guimerà et al. 1995). The Cameros Basin was formed during Late Jurassic to Early
Cretaceous intraplate rifting in Iberia as a consequence of the opening of the North Atlantic Ocean. The infill of this extensional basin corresponds to a large cycle or super-sequence divided into eight depositional sequences, and it registers high subsidence and accumulation rates, with a stratigraphic record of more than $9000 \mathrm{~m}$ of sediments from the Tithonian to the early Albian (Mas et al. 1993, 2002; Arribas et al. 2003) (Fig. 2). These depositional sequences consist of alluvial, fluvial, and lacustrine deposits, with rare marine incursions from the Tethys Sea (Mas et al. 1993, 2002).

The Oncala Group corresponds to the third depositional sequence (Fig. 2) and is Berriasian in age (Salomon 1982; Martín-Closas 1989; Schudack and Schudack 1989, 2009). This group has been subdivided into two units (Guiraud and Seguret 1985; Mas et al. 1993; Gómez-Fernández and Meléndez 1994): the Huérteles Formation and the Valdeprado Formation. Siliciclastic facies predominate in the first formation, whereas carbonate facies are dominant in the second. The deposits detailed here are situated in the eastern part of the Valdeprado Formation (Fig. 1A, B), which consists mainly of millimeter- to centimeter-thick, laminated carbonate (Figs. 3, 4A). These laminated carbonates crop out extensively over an area approximately $40 \mathrm{~km}$ long and $3 \mathrm{~km}$ wide in the eastern Cameros Basin, and they have been interpreted previously as having formed in deep carbonate lakes (Gómez-Fernández and Meléndez 1994; Meléndez and Gómez-Fernández 2000).

Laminated carbonates of the Valdeprado Formation pass laterally to proximal siliciclastic facies in the western area of the basin. These proximal siliclastic facies are made up of channeled sandstone and siliciclastic mudstone, and they contain abundant desiccation mudcracks, which are evident at the top of almost every siliciclastic mudstone lamina and commonly are associated with ubiquitous vertebrate footprints (226 tracksites of theropod, ornithopod, sauropod, pterosaur, bird, crocodile, and turtle have been found to date, Hernández et al. 2005-2006; Moratalla and Hernán 2010). This siliciclastic facies have been interpreted as deposited in sandy-muddy flats (Gómez-Fernández and Meléndez 1994; Meléndez and Gómez-Fernández 2000; Quijada et al. 2010).

The extensive outcrops of the Valdeprado Formation allow the observation of the depositional geometry of the laminated carbonates and their lateral relationship with the western siliciclastic deposits (Fig. 4B, C). The lateral transition from laminated carbonate to siliciclastic deposits is gradual, and in the western area of the basin, the carbonate and siliciclastic facies are interbedded directly, without any other facies in between. Both carbonate and siliciclastic deposits show parallel layering, and are laterally continuous over hundreds of meters, and no clinoforms, marked gradients, or gravity structures, such as slump structures or slide masses, have been recognized in the area (Fig. 4B, C).

\section{FACIES OF THE LAMINATED CARBONATES OF THE VALDEPRADO FORMATION}

The carbonate deposits of the Valdeprado Formation in the eastern area of the basin (Fig. 1B) include over $900 \mathrm{~m}$ of a succession consisting mainly of laminated limestones (Fig. 3). Within these laminated limestones, individual laminae can be followed tens or even hundreds of meters along the total length of the outcrop (Fig. 4A). In this succession, seven facies were distinguished (Table 1, Fig. 3): 1) parallellaminated limestone, 2) graded-laminated limestone, 3) cross-laminated arenite, 4) carbonate breccia, 5) shale, 6) ostracode mudstone to wackestone with centimeter-size pseudomorphs after gypsum, and 7) ostracode and gastropod wackestone to packstone.

\section{Facies 1. Parallel-Laminated Limestone}

One of the most abundant facies in the formation (Fig. 3) consists of alternating parallel laminae of carbonate mudstone, and calcite and 


\section{(A)}

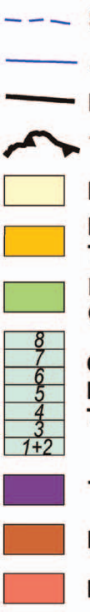

Syncline

Anticline

Fault

Thrust

Post-tectonic Tertiary

Pre and Syntectonic

Tertiary

Late Albian-Late

Cretaceous

Cameros Basin infilling

Depositional Sequences (DS):

Tithonian-Early Albian

Triassic and Jurassic

Post-Variscan Paleozoic

Hercynian Basement

|3OW OLOGROÑO

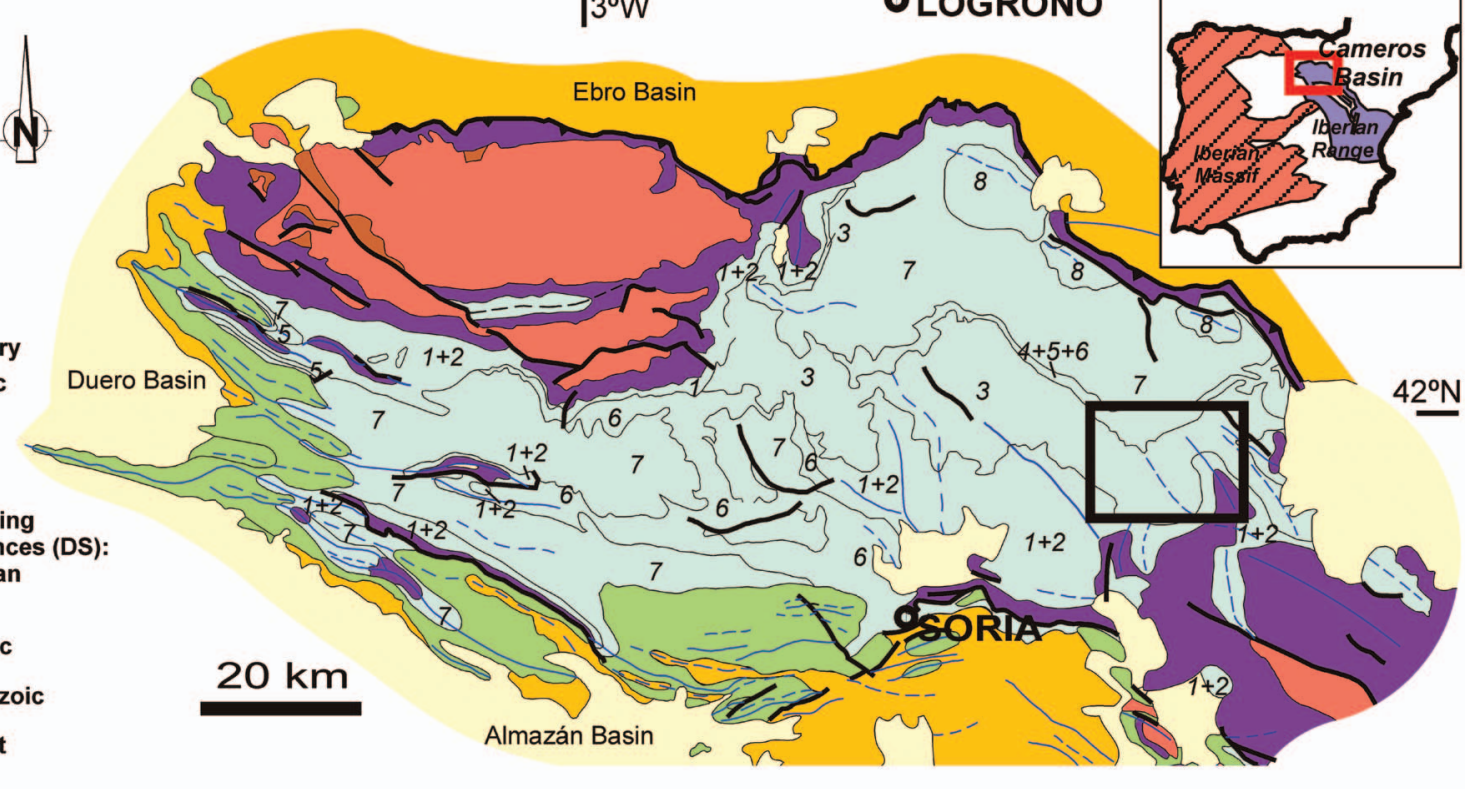

(B)

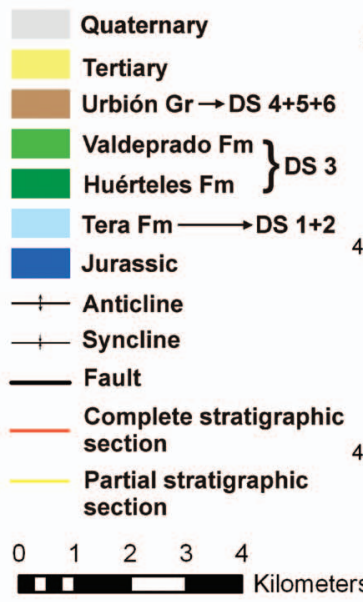

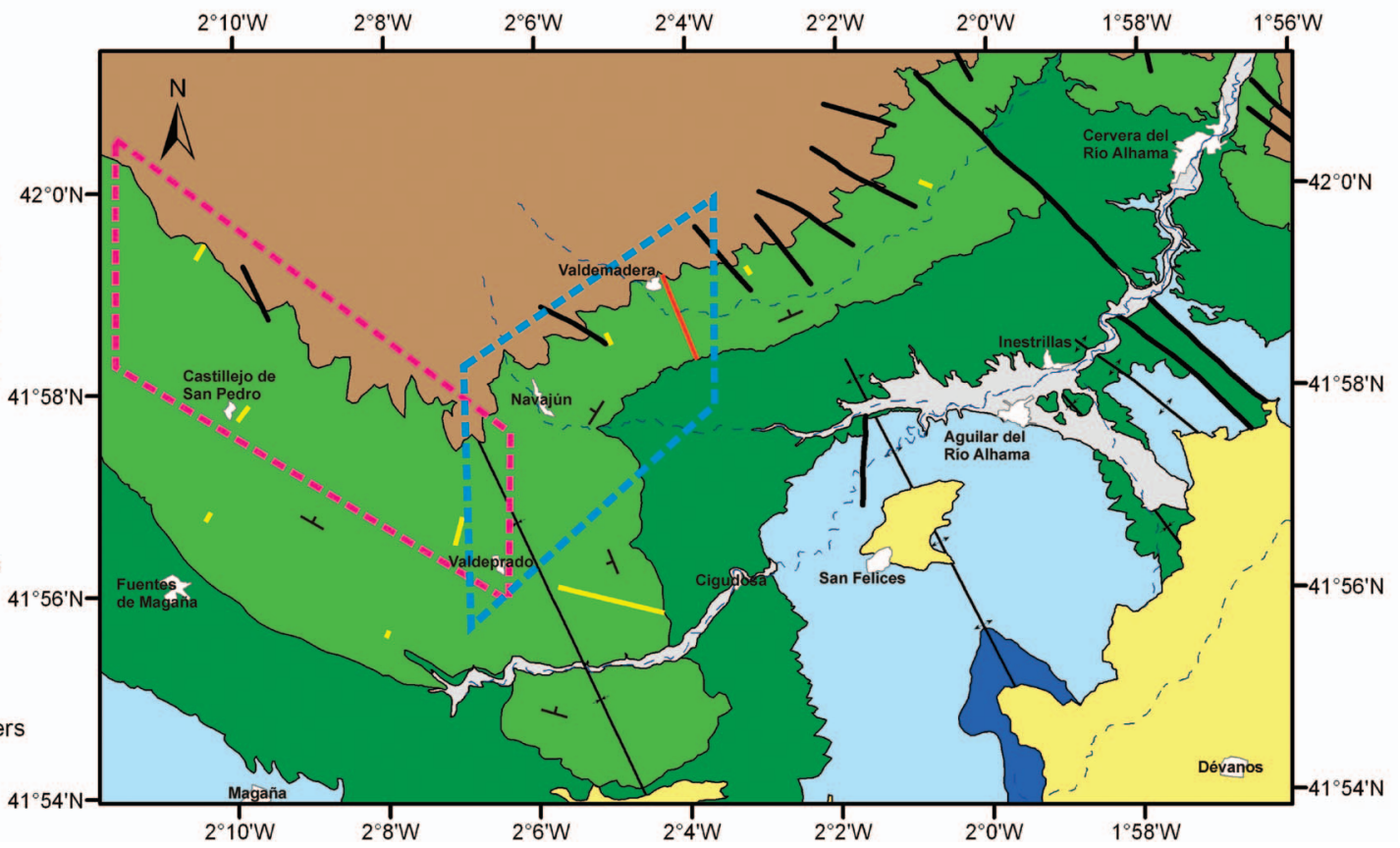

FIG. 1.-A) Geological map of the Cameros Basin (modified from Mas et al. 2002). The black rectangle marks the mapped area in Part B. B) Detailed geological map of the study area. The red line marks the position of the complete stratigraphic section measured from the base to the top of the formation, and the yellow ones show the location of partial stratigraphic sections. The blue rectangle marks the panoramic photograph shown in Figure $4 \mathrm{~B}$, and the pink rectangle, the panoramic photograph shown in Figure 4C.

quartz (Fig. 5A, B). This facies is interbedded with graded-laminated limestone (Facies 2), which is the other most abundant facies in the Valdeprado Formation, and with all the other facies except the ostracode and gastropod wackestone to packstone (Facies 7), described below.

Mudstone laminae are generally submillimeter- to millimeter-thick, but a few laminae reach $10 \mathrm{~cm}$ in thickness. They contain carbonate mudstone with some dispersed silt-size grains of quartz, calcite, and muscovite, and calcite and quartz pseudomorphs after (sub-) millimeter-size lenticular gypsum. Some of the mudstone laminae contain fine-sand-size peloids, or micropeloidal texture instead of homogeneous texture. Stromatolites up to $5 \mathrm{~cm}$ thick are evident. They consist of laminae up to $1.6 \mathrm{~mm}$ thick, which display planar to domed shapes and peloidal, clotted-peloidal, fenestral, and dense micrite microfabrics (Fig. 5C, D).

Calcite and quartz laminae generally are submillimeter- to millimeterthick, although layers up to $2 \mathrm{~cm}$ are also present. In general, these laminae are thinner than the mudstone laminae. Most are tabular, but some display concave bases and flat or convex tops. The calcite and quartz laminae consist of aggregates of pseudomorphs after crystals displaying lenticular habit (Fig. 5A, B), which is not a characteristic habit of quartz or calcite but it is typical of displacive gypsum (Magee 1991; Kendall 1992; Ortí 2010a). The carbonate mudstone matrix is deformed around the pseudomorphs (Fig. 5B), which is also distinctive of displacive 


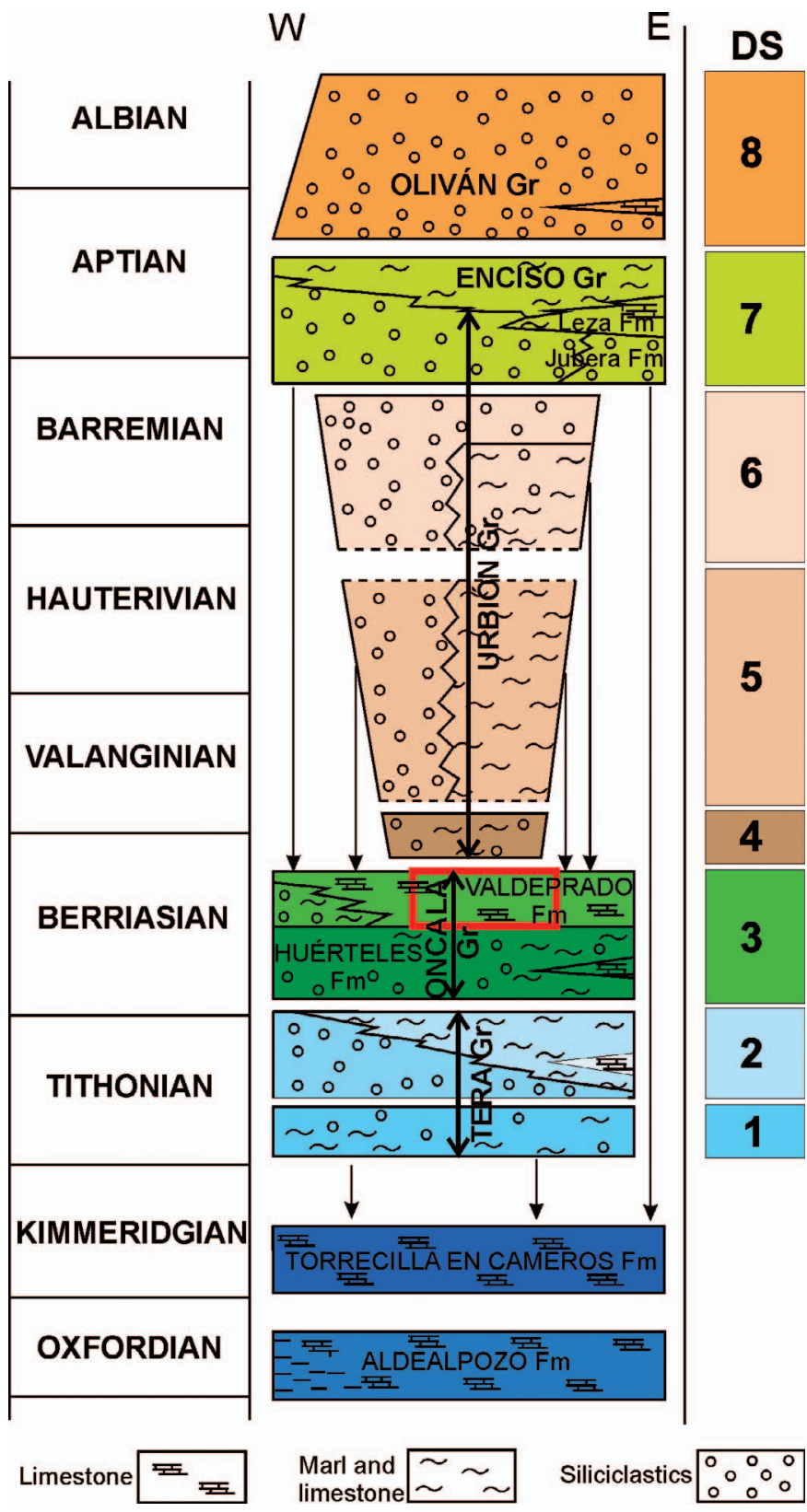

FIG. 2.-Stratigraphic framework and depositional sequences (DS) filling the eastern Cameros Basin. The focus of this study, the Valdeprado Formation, is highlighted with a red rectangle. Modified from Mas et al. (2004). "Gr." = group, "Fm" = formation. evaporites, although deformation around crystals could have been exaggerated during early diagenesis because gypsum crystals do not compact but the soft matrix does.

\section{Facies 2. Graded-Laminated Limestone}

This facies is very abundant in the Valdeprado Formation (Fig. 3) and is interbedded with the parallel-laminated limestone facies (Facies 1), as well as with all the other facies except the ostracode and gastropod wackestone to packstone (Facies 7). The graded-laminated limestones commonly begin at an erosional base overlain by silt- to fine-sand-size grains, and gradually change upwards to carbonate mudstone (Fig. 6A, B). Laminae are generally submillimeter to millimeter thick, but they may be up to a few centimeters thick. The detrital components are ostracode fragments, grains of quartz and muscovite, and quartz and calcite pseudomorphs probably after detrital gypsum, because they display irregular lenticular shapes and replacements identical to the lenticular crystals in the parallel-laminated limestones (Facies 1). Intraclasts are present at the base of some laminae; they are clasts of carbonate mudstone and sulfate laminae replaced by calcite and quartz, similar to those in the parallel-laminated limestone (Fig. 6C). Calcite and quartz pseudomorphs after lenticular gypsum are distributed randomly in some layers.

Mudcracks are present in some layers at the top of the graded laminae (Fig. 7A-E). Few mudcracked laminae are scattered in the lower and middle part of the stratigraphic section (none to few mudcracked laminae per tens of meters of deposit), and they are especially abundant in two stratigraphic intervals situated in the middle part of the section $(620$ $625 \mathrm{~m}$ in Fig. 3) and in the upper part of the section (920-950 $\mathrm{m}$ in Fig. 3). In these two stratigraphic intervals, cracks occur at the tops of successive laminae (up to 25 mudcracked laminae per meter of deposit are present; Fig. 7A, B). Individual cracks range from less than $1 \mathrm{~mm}$ to $3 \mathrm{~mm}$ in width, and from less than a millimeter to $3 \mathrm{~cm}$ in depth. The mudcracks have well-developed, centimeter-size polygonal patterns in plan view and taper gradually downward from the top displaying a v-shaped profile (Fig. 7B). Upward curling is evident in some cracked beds. Two types of infill are distinguished in these mudcracks. Some cracks are filled with stratified, silty carbonate mudstone and thin laminae of ostracode wackestone, which derive from overlying beds (Fig. 7E). Yet, most of the mudcracks are filled with calcite and quartz pseudomorphs after rectangular crystals resembling anhydrite (Fig. 7D, F), which deform the matrix around them.

\section{Facies 3. Cross-Laminated Arenite}

Several layers of cross-laminated arenites (rocks consisting of grains from 0.0625 to $2 \mathrm{~mm}$ in diameter, regardless of composition and genesis, sensu Grabau 1904, 1913; Zuffa 1980) are present from the bottom to the top of the formation, alternating with parallel-laminated limestone (Facies 1) and graded-laminated limestone facies (Facies 2), but they are much more abundant in the upper part of the stratigraphic section than below (Fig. 3). They form layers ranging from a few millimeters to $2 \mathrm{~cm}$ in thickness. These arenites comprise fine-sand-size calcite and

FIG. 3. - Stratigraphic section of the complete Valdeprado Formation in the area near Valdemadera. The numbers in the right column indicate the different facies: 1) parallel-laminated limestone, 2) graded-laminated limestone, 3) cross-laminated arenites, 4) carbonate breccia, 5) shale, 6) ostracode mudstone to wackestone with centimeter-size pseudomorphs after gypsum, 7) ostracode and gastropod wackestone to packstone. Notice that facies 1 and 2 are the most abundant along the stratigraphic section; facies 1 to 6 are associated with each other (note that facies 6 is present only in the upper part of the formation); facies 7 is exclusively associated with facies 5, and is present only in the uppermost $13 \mathrm{~m}$ of the succession; mudcracked laminae are scattered from the base to the top of the formation, but they are especially abundant in two stratigraphic intervals (indicated with black arrows); and cross-laminated laminae are also present from the base to the top of the unit, but they are more abundant in the upper part of the succession. 


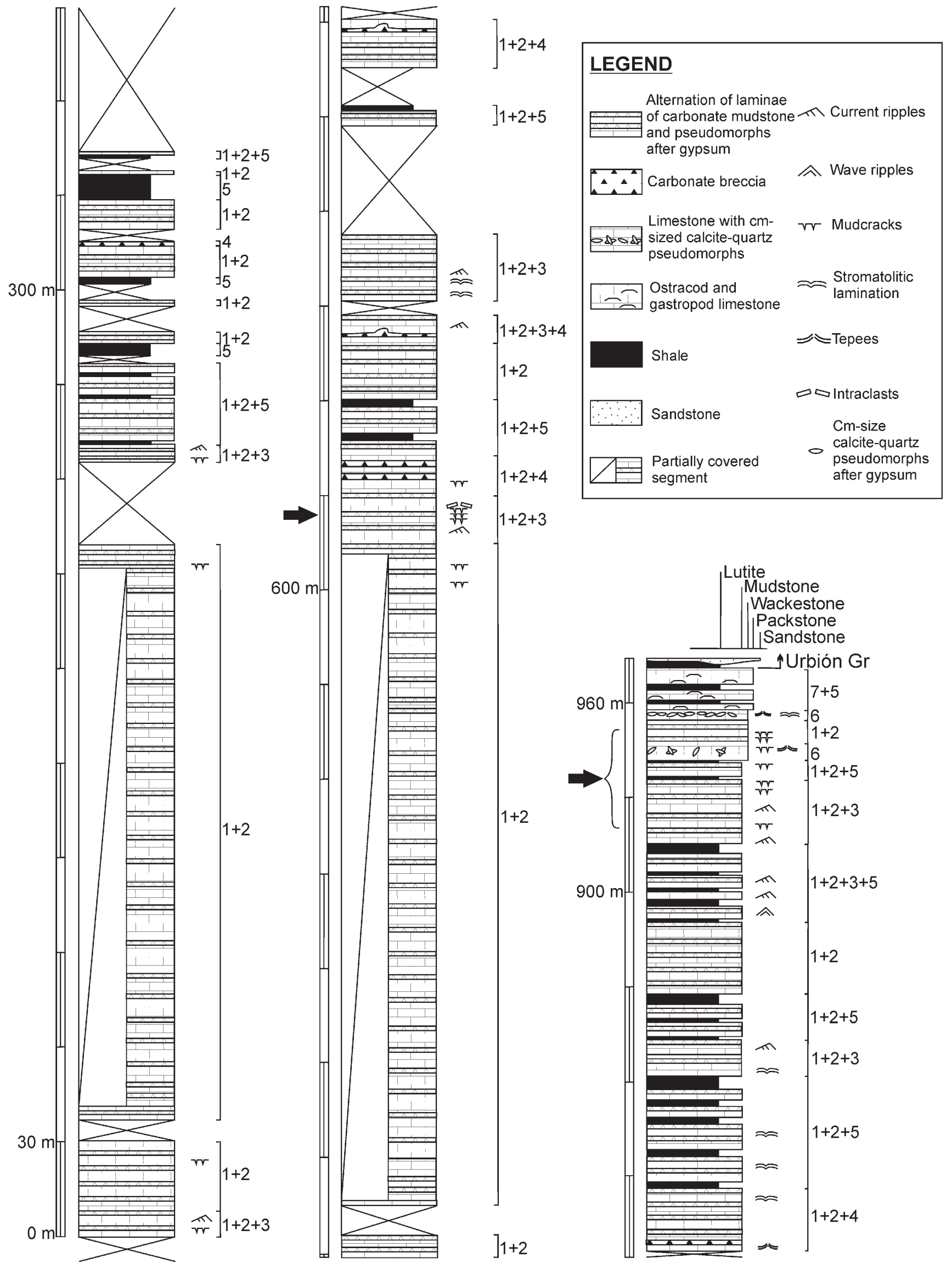



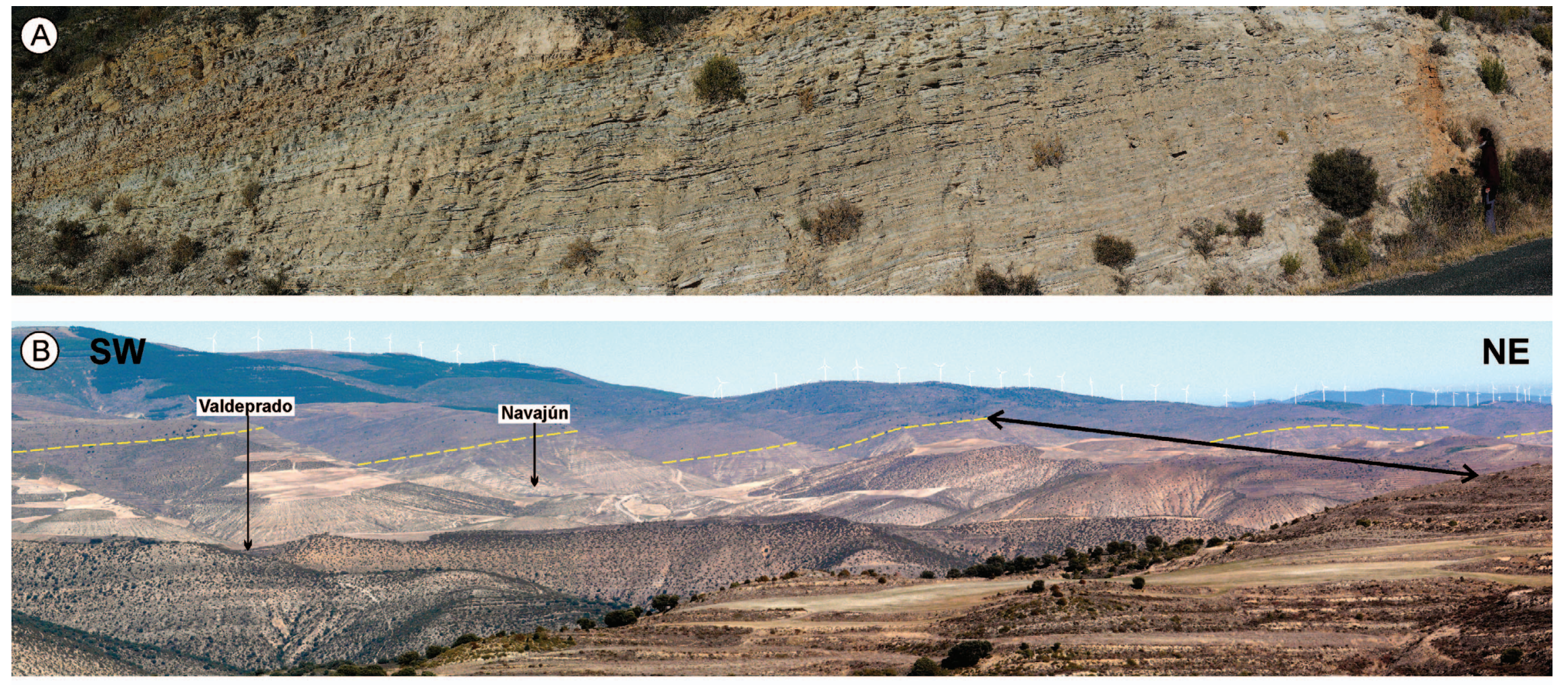

NE

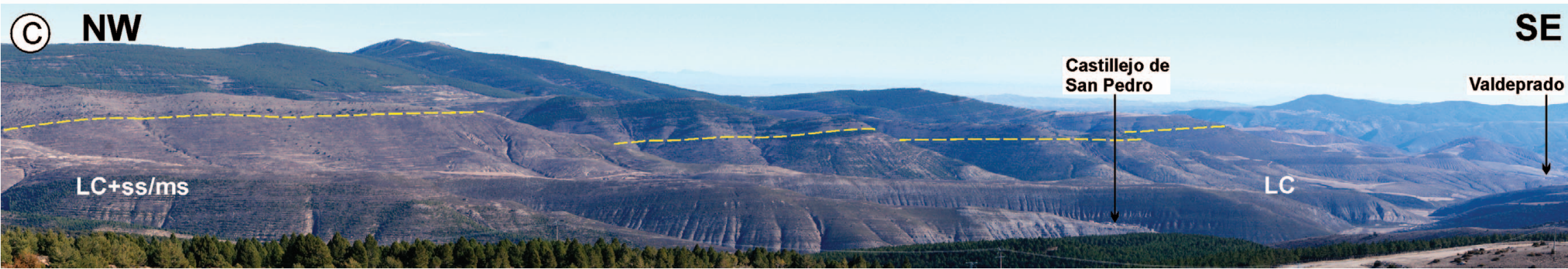

FIG. 4.-A) Field photograph of laminated carbonates of the Valdeprado Formation showing the continuous parallel lamination that characterizes this unit (person in the right area is $1.7 \mathrm{~m}$ tall). B) Panoramic photograph of the eastern area of the Valdeprado Formation (location indicated in Fig. 1B) showing the continuous and parallel layering that characterizes this formation. The black arrow marks the approximate situation of the complete stratigraphic section measured in the unit. The contact with the overlying Urbión Group is marked with yellow lines (the apparent drop of these lines is due to an optical illusion caused by the valleys). C) Panoramic photograph of the Valdeprado Formation in the area adjacent to Part B (location shown in Fig. 1B), where laminated carbonate (LC) pass to laminated carbonates interbedded with sandstones and siliciclastic mudstones $(\mathrm{LC}+\mathrm{ss} / \mathrm{ms})$. This area is also characterized by continuous parallel layering. The contact with the overlying Urbión Group is marked with yellow lines 
TABLE 1.-Facies of the Valdeprado Fm in the eastern area of the Cameros Basin.

\begin{tabular}{|c|c|c|}
\hline Facies & Characteristics & Processes \\
\hline 1. Parallel-laminated limestone & $\begin{array}{l}\text { (Sub-) millimeter-thick lamination; alternation of micrite } \\
\text { and pseudomorphs after gypsum laminae; (micro-) } \\
\text { peloids and stromatolites. }\end{array}$ & $\begin{array}{l}\text { Precipitation of micrite and evaporites caused by salinity } \\
\text { fluctuations. }\end{array}$ \\
\hline 2. Graded-laminated limestone & $\begin{array}{l}\text { (Sub-) millimeter-thick lamination; erosional base } \\
\text { overlain by ostracode fragments, grains of quartz and } \\
\text { mica and detrital gypsum, grading upwards to carbonate } \\
\text { mudstone; mudcracks at the top of scarce laminae. }\end{array}$ & $\begin{array}{l}\text { Sediment resuspension and subsequent deposition, } \\
\text { followed by evaporation of water and episodic } \\
\text { subaerial exposure. }\end{array}$ \\
\hline 3. Cross-laminated arenite & $\begin{array}{l}\text { Current and wave ripples; pseudomorphs after detrital } \\
\text { gypsum grains, peloids, ostracode fragments, quartz, } \\
\text { and mica. }\end{array}$ & Currents and waves affecting the bottom of the lake. \\
\hline 4. Carbonate breccia & $\begin{array}{l}\text { Fragments of carbonate mudstone with pseudomorphs } \\
\text { after sulfates within a matrix of pseudosparitic calcite. }\end{array}$ & $\begin{array}{l}\text { Deposits originally constituted by alternating laminae of } \\
\text { carbonate mudstone and sulfate, brecciated as the } \\
\text { result of tectonic deformation. }\end{array}$ \\
\hline 5. Shale & $\begin{array}{l}\text { Thinly laminated; fissile; ochre to purple-colored; clays, } \\
\text { quartz, oxides, carbonate and ostracodes. }\end{array}$ & Siliciclastic discharges. \\
\hline $\begin{array}{l}\text { 6. Ostracode mudstone to wackestone with } \\
\text { centimeter-size pseudomorphs after gypsum }\end{array}$ & $\begin{array}{l}\text { Ostracode mudstone to wackestone with large calcite and } \\
\text { quartz pseudomorphs after gypsum; mudcracks; tepees. }\end{array}$ & $\begin{array}{l}\text { Carbonate precipitation followed by desiccation and } \\
\text { subaerial exposure. }\end{array}$ \\
\hline $\begin{array}{l}\text { 7. Ostracode and gastropod wackestone } \\
\text { to packstone }\end{array}$ & $\begin{array}{l}\text { Alternation of mudstone laminae and ostracode and } \\
\text { gastropod wackestone to packstone laminae. }\end{array}$ & $\begin{array}{l}\text { Precipitation of carbonates in lakes with more frequent } \\
\text { freshwater input. }\end{array}$ \\
\hline
\end{tabular}

quartz pseudomorphs probably after detrital gypsum grains, peloids, ostracode fragments and, in a minor proportion, quartz and mica. They are grain-supported and typically include current-ripple cross-lamination (Fig. 8A, B). Approximately 1-cm-thick wave ripples with gently dipping foresets (under $10^{\circ}$ ) are also observed (Fig. 8C, D).

\section{Facies 4. Carbonate Breccia}

This facies is present from the base to the top of the Valdeprado Formation in beds from several millimeters to $20 \mathrm{~cm}$ in thickness (Fig. 3). The breccias are made up of millimeter-size to 4-cm-size angular fragments of carbonate mudstone floating in a matrix of pseudosparitic calcite (Fig. 9A). Fragments consist of carbonate mudstone with calcite and quartz pseudomorphs after sulfates, identical to those of the parallellaminated limestone facies. In some layers, the original lamination is preserved, because there is little displacement of the fragments; in other layers the original lamination is totally disrupted and the breccias are matrix-supported and chaotic. Some laminae are broken and disrupted in some areas and, laterally, they are unbroken (Fig. 9B). The breccias are commonly related to tectonic structures, such as fractures or folds (Fig. 9B), and the fragments are usually oriented parallel to the flanks of the folds.

\section{Facies 5. Shale}

Several shale beds, ranging in thickness from a few centimeters to $8 \mathrm{~m}$, are present from the base to the top of the stratigraphic section (Fig. 3), and are interbedded with all the other facies in the formation. They are very thinly laminated, showing conspicuous fissility, and varying in color from ochre to light purple (Fig. 9C). These layers are composed of clay, very-fine-silt-size quartz grains, iron oxides, and variable carbonate contents, and they commonly contain ostracodes.

\section{Facies 6. Ostracode Mudstone to Wackestone with Centimeter-Size Pseudomorphs after Gypsum}

This facies, present in the upper part of the Valdeprado Formation (Fig. 3), is associated with parallel-laminated limestone (Facies 1) and graded-laminated limestone (Facies 2). It consists of ostracode mudstone to wackestone with large calcite and quartz pseudomorphs after gypsum (Fig. 10A, B). This facies is parallel-laminated, and some laminae have slightly erosional bases, above which lie silt-size to very fine-sand-size ostracodes, calcite pseudomorphs after probable detrital gypsum grains, and quartz and mica grains.

The centimeter-size calcite and quartz pseudomorphs after gypsum present in this facies display lenticular morphologies, and they deform the surrounding matrix. These pseudomorphs are organized into horizontal layers within the ostracode mudstone to wackestone (Fig. 10B), or along vertical structures associated with abundant mudcracks and tepees (Fig. 10A, C). The mudcracks are up to $4 \mathrm{~cm}$ deep, taper downward, and contain millimeter-size calcite pseudomorphs after lenticular sulfates, in addition to the associated larger pseudomorphs (Fig. 10A). Rare tepee structures are $5 \mathrm{~cm}$ in height, and the distance among them is roughly $20 \mathrm{~cm}$ (Fig. 10C).

\section{Facies 7. Ostracode and Gastropod Wackestone to Packstone}

The uppermost $13 \mathrm{~m}$ of the Valdeprado Formation is made up of bioclastic limestone interbedded with shale (Fig. 3). Limestone beds vary from $50 \mathrm{~cm}$ to $5 \mathrm{~m}$ in thickness, whereas the less abundant shale beds are less than $20 \mathrm{~cm}$ thick. Ostracode and gastropod wackestone to packstone facies is present only at the top of the section and is not associated with parallel-laminated limestone (Facies 1), graded-laminated limestone (Facies 2), or any other facies apart from shale.

The limestone consists of alternating laminae of mudstone and ostracode and gastropod wackestone to packstone (Fig. 10D). Rare subspherical and displacive nodules, up to $6 \mathrm{~cm}$ in size, composed of calcite, quartz, and dolomite, are randomly distributed in the limestone (Fig. 10E). Acicular crystals resembling anhydrite laths (Ciarapica et al. 1985; Ortí and Rosell 1997) are visible within the quartz and dolomite of the nodules under the petrographic microscope.

\section{DISCUSSION}

Parallel-laminated limestone (Facies 1, alternating laminae of mudstone and pseudomorphs after gypsum) and graded-laminated limestone (Facies 2, commonly with an erosional base overlain by silt-size to finesand-size grains, gradually grading upwards to carbonate mudstone) are the two most abundant facies in the study area. Similar facies have been described in both deep (Smoot 1991; Last and Vance 1997) and shallow (Schreiber et al. 1976; Mitchell 1985; Gibert et al. 2007) environments. For this reason, interpretation of the depth of deposition requires detailed analysis of their sedimentary features, associated facies, and lateral relationships with adjacent deposits. 

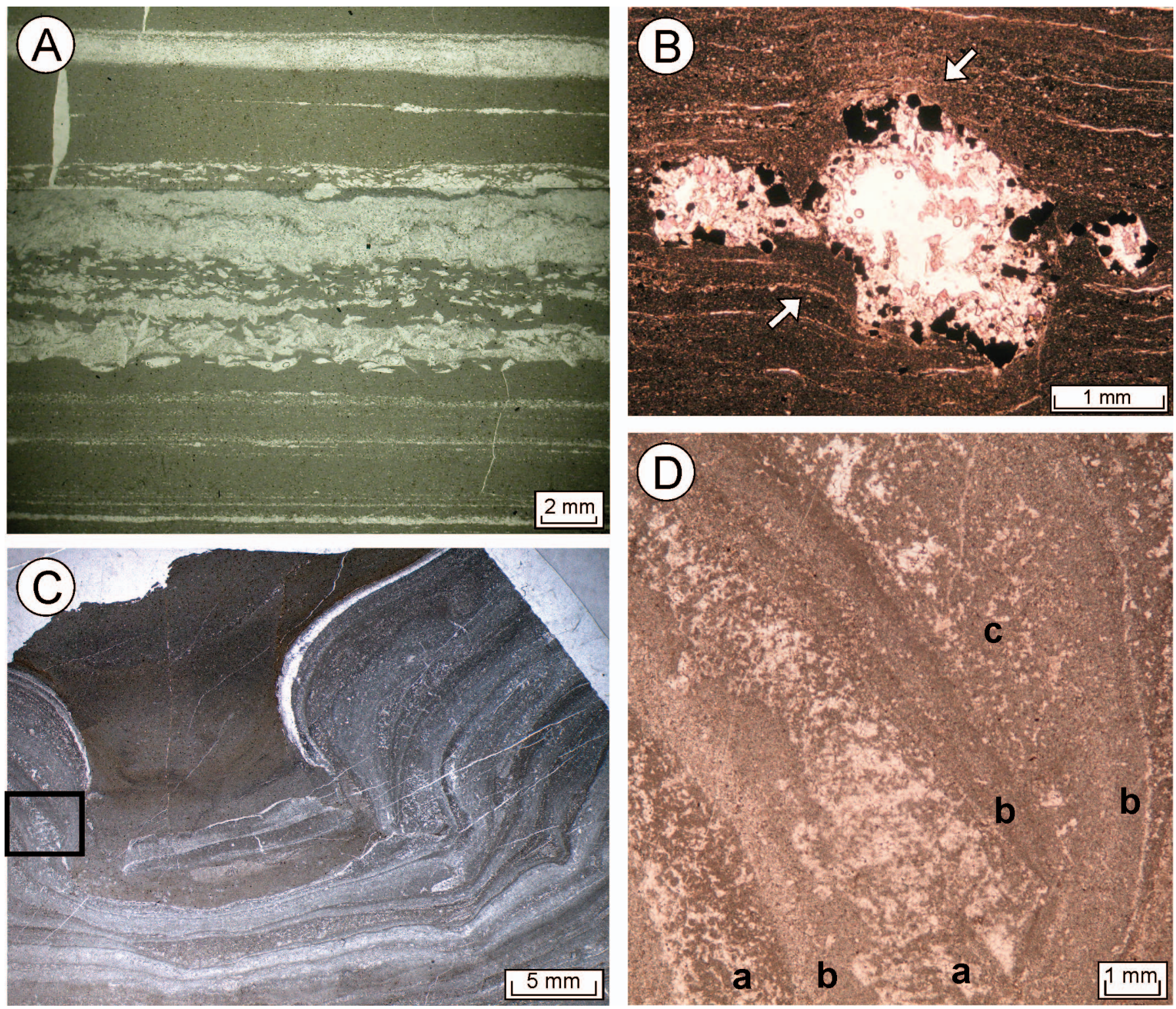

FIG. 5.-Photos of parallel-laminated limestone facies. A) Thin-section photomicrograph of the alternation of laminae of micrite and pseudomorphs after gypsum. B) Thin-section photomicrograph of calcite and quartz pseudomorphs after lenticular gypsum nodules. Note the displacement in the matrix around the nodules (white arrows). The black crystals are pyrite cubes. Thin section was stained with alizarin red. C) Thin-section photomicrograph of stromatolitic laminae displaying domed shapes and alternating microfabrics. The rectangle marks the area shown in Part D. D) Microscopic detail of stromatolitic laminae displaying (a) clotted-peloidal, (b) dense micritic, and (c) fenestral microfabrics. Thin-section photomicrograph.

The sedimentary features observed in parallel-laminated limestone can be explained as the result of deposition in a body of water with alternating flooding and evaporative intervals, as described in several saline environments such as perennial saline lakes, saline pans, and coastal salinas (Lowenstein and Hardie 1985; Smoot and Lowenstein 1991; Schubel and Lowenstein 1997; Makhlouf and Aziz El-Hadad 2006; Gibert et al. 2007). The alternation of flooding and evaporation caused salinity fluctuations, which led to an alternating deposition of mudstone and precipitation of evaporitic layers under calm conditions without action of currents or agitation. During lower-salinity periods, such as after water discharge, carbonate mud with micropeloidal textures, peloids, and stromatolites accumulated. These textures suggest that, at least in some levels, the precipitation of carbonate mud was mediated by microbial activity, such as in-place mineralization via organic matrices or carbonate precipitation induced by metabolic processes that shift the solubility equilibrium (cf. Reitner 1993; Riding 2000; Pomar and Hallock 2008; Flügel 2010). As the water evaporated, the sulfate saturation increased and lenticular gypsum crystals grew displacively within the mud, in the upper part of the sedimentary column, or at the sedimentwater interface, as evidenced by the deformation of the surrounding matrix. Lenticular gypsum thus is interpreted as a syndepositional diagenetic phase that was formed while the sediment was still soft. Equivalent displacive evaporites are characteristic of sabkhas, saline mudflats, or perennial saline lakes (e.g., Hardie et al. 1978; Smoot and Lowenstein 1991; Demicco and Hardie 1994; Warren 2006; Ortí 2010b; and references therein). The development of intrasediment gypsum, and absence of cumulates or selenites, may be related to the salinity range. Studies of salt works of the Mediterranean coast show that fine laminae 

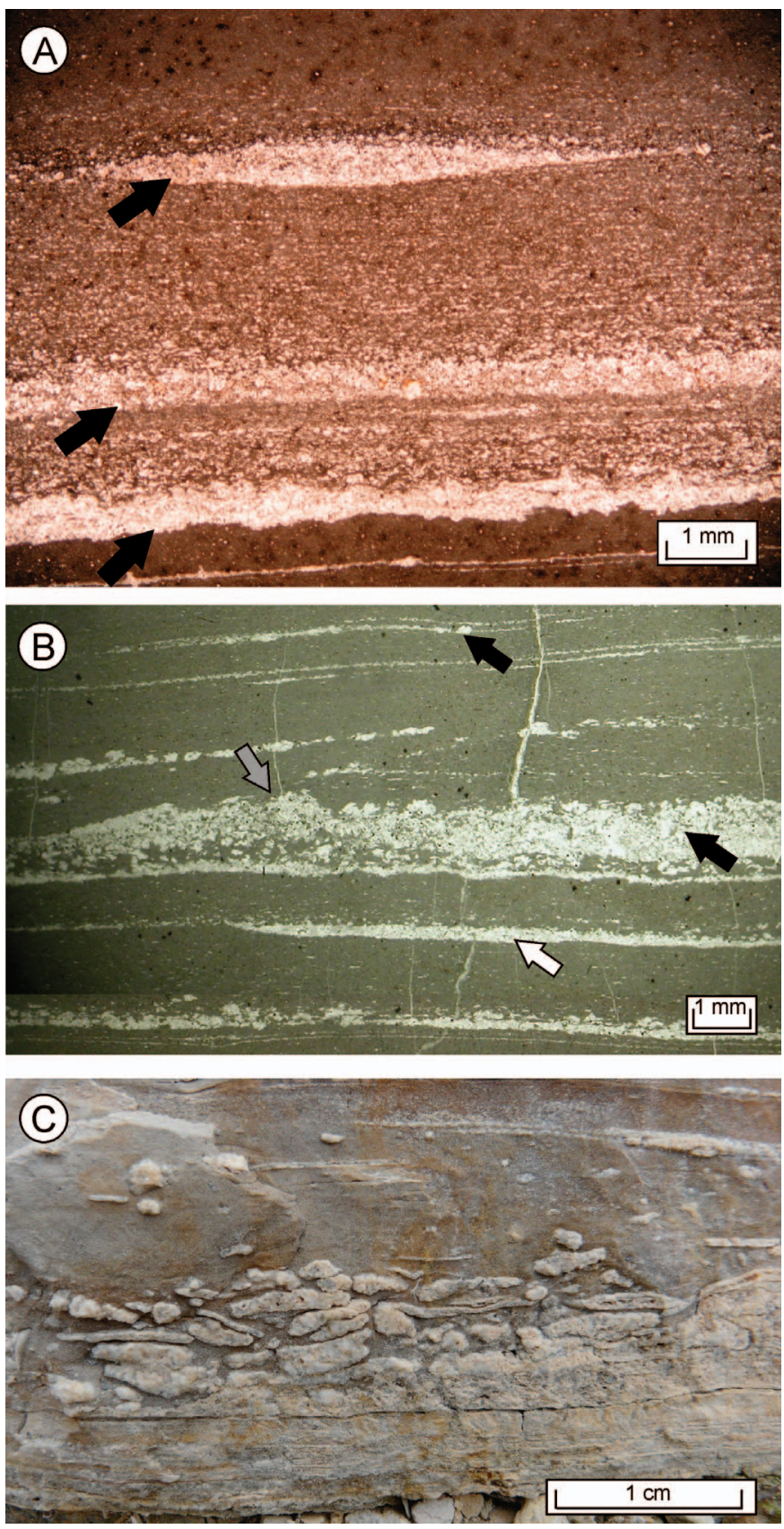

FIG. 6.-Graded-laminated limestone facies. A) Thin-section photomicrograph of three laminae of graded-laminated limestone with erosional bases (signaled by arrows). B) Alternation of graded-laminated limestone (white arrow) and parallellaminated limestone facies (black arrows). Note the erosional base of the lamina marked with a gray arrow. Thin-section photomicrograph. C) Intraclasts at the base of a layer. Intraclasts are made up of reworked laminae consisting largely of pseudomorphs after gypsum.

of gypsum crystals precipitate within laminated microbial mats at a salinity close to $140 \mathrm{~g} \mathrm{l}^{-1}$, whereas gypsum cumulates and selenitic crusts require salinities above $140 \mathrm{~g} \mathrm{l}^{-1}$ and $230 \mathrm{~g} \mathrm{l}^{-1}$, respectively (Ortí 2010b, 2011). Based on this analog, water bodies of the Valdeprado Formation probably did not exceed salinities of about $140 \mathrm{~g}^{-1}$.

Although these observations provide information on salinity fluctuations in the depositional environment, depth-distinctive sedimentary features are not evident in this facies. Nonetheless, considering that salinity fluctuations accompanied by precipitation of evaporites with different solubilities have been described in extant shallow environments, such as intertidal areas or saline ephemeral lakes (Schreiber et al. 1976; Lowenstein and Hardie 1985), and that stromatolites are commonly an indicator of deposition in the photic zone (e.g., Platt and Wright 1991; Fregenal-Martínez and Meléndez 2010; Gierlowski-Kordesch 2010; and references therein), the hypothesis of shallow depositional depth must be considered. The preservation of laminated carbonates and gypsum indicates minimum reworking and bioturbation, which are possible in shallow environments under certain conditions. Well-developed saline stratification (Kendall 1992) and elevated water density and viscosity can damp wave and current motion at shallow depths, and high rates of accumulation can also prevent long periods of reworking. The lack of burrowing in a shallow setting may be the result of high and fluctuating salinities, impeding the presence of burrowing organisms (GierlowskiKordesch and Rust 1994; Renaut and Gierlowski-Kordesch 2010), plus a high rate of accumulation of organic matter, which possibly created anoxic conditions in the sediments (Buscalioni and Fregenal-Martínez 2010).

The similarity between the parallel-laminated limestone facies (Facies 1) and the fragments of the carbonate breccias of the Valdeprado Formation (Facies 4), which consist of fragments of carbonate mudstone with pseudomorphs after sulfates, suggests that, prior to brecciation, the brecciated layers consisted of parallel-laminated limestones. In fact, alternation of laminae of mudstone and pseudomorphs after gypsum is observed in areas where the original lamination is still preserved in the brecciated layers (Fig. 9B). Although carbonate breccias may form as the result of deposition of eroded carbonate material and, consequently, give information about the depositional environment, several features suggest that the carbonate breccias of the Valdeprado Formation are not sedimentary, but the result of structural deformation while at burial depths. At burial depths, limestones and sulfates (the two lithologies that originally made up these layers) have very different rheological behaviors: brittle and ductile, respectively (Müller and Briegel 1978; Schreiber and Helman 2005). As a consequence, sulfate laminae in the Valdeprado Formation flowed during tectonic deformation and interbedded carbonate laminae, which were brittle, were broken and rotated, as described in other ancient sulfate-carbonate formations (Helman and Schreiber 1985; Lugli 2001). The final result of this process was the formation of a breccia made up of angular carbonate fragments floating within a sulfate groundmass. Depending on factors such as the amount of sulfate or differential stress applied, different degrees of brecciation affected the alternation of carbonate and sulfate laminae in the Valdeprado Formation, from undisrupted layers (parallel-laminated limestone facies) to slightly disrupted (carbonate breccias where the original lamination is distinguishable) and totally disrupted layers (chaotic carbonate breccias). The association of breccias with tectonic structures such as folds or fractures is also consistent with this interpretation (Fig. 9B). During diagenesis, the sulfate matrix of these breccias was replaced by pseudosparitic calcite, as occurred with all the sulfates in the Valdeprado Formation.

The graded-laminated limestone (Facies 2), the other most abundant facies in the succession, is not a depth-defining facies per se either. Similar facies have been observed in deep lakes as the result of turbidity underflows triggered by gravity instability or sediment-laden fluvial discharge entering lower-density water (Ludlam 1974; Lambert and Hsü 1979; Mingram 1998; Freytet and Verrecchia 2002; Corella et al. 2011a, 2011b). However, graded-laminated limestones have also been described in playa lakes and shallow saline lakes (Eugster and Hardie 1975; Hardie et al. 1978; Smoot 1983; Paik and Kim 2006) and continental wetlands (Buscalioni and Fregenal-Martínez 2010), as the result of sedimentcharged water currents followed by deposition of mudstone when calm conditions are recovered. In shallow water bodies, sediment resuspension 

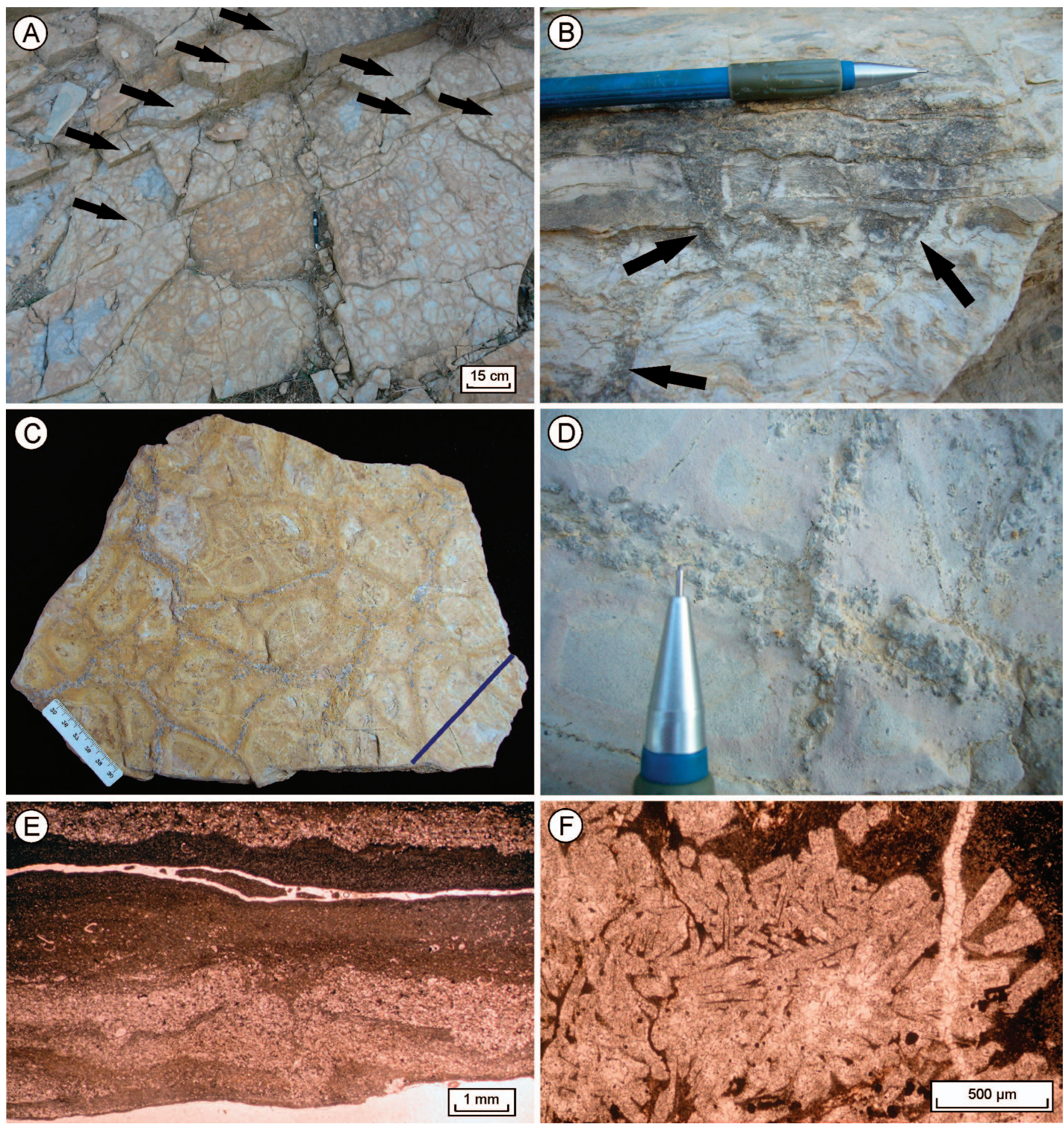

FIG. 7.-Graded-laminated limestone with mudcracks. A) Tops of several laminae with polygonal mudcracks. Note that the mudcracks are present in several successive laminae (arrows). B) Desiccation mudcracks taper downwards, developing v-shape profiles. Note that they are present in successive laminae separated stratigraphically by only few centimeters. C) Desiccation mudcracks at the top of a lamina. The blue line indicates the position where the thin section shown in Part E was performed. D) Pseudomorphs after anhydrite associated with mudcracks. E) Microscopic detail of a downward-tapering desiccation crack filled with material from above. Note the upward curling of the cracked beds. Thin-section photomicrograph. F) Thin-section photomicrograph of calcite pseudomorphs after anhydrite within the mudcracks.

is a common process that produces graded laminae, in that it includes erosion of fine-grained sediments from the bottom (top uncompacted material is easily resuspended), distribution of this material by currents, and settling when calm conditions are recovered (Bengtsson and
Hellström 1992; Jin and Sun 2007). It may be caused by wind-induced water currents, wave action, and/or seiches (Bengtsson and Hellström 1992; Shteinman et al. 1997; Jin and Sun 2007; Renaut and GierlowskiKordesch 2010; Kelderman et al. 2012), and also by storm events (Evans 

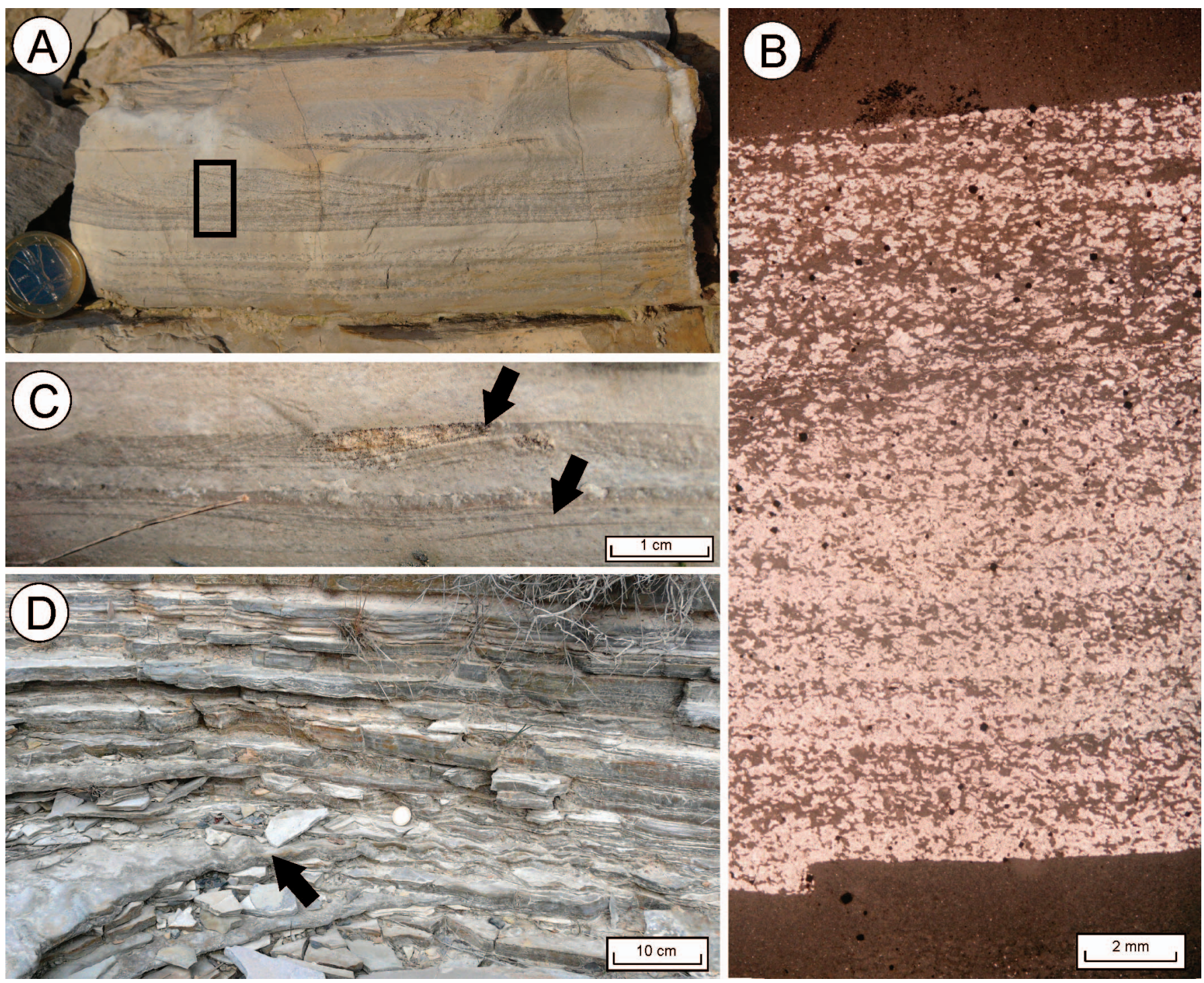

FIG. 8. - Cross-laminated arenite facies. A) Current ripples in arenites. The rectangle marks the area shown in Part B. B) Thin-section photomicrograph of the currentripple cross-laminated arenite. The rock includes peloids and lenticular sparitic grains, interpreted as pseudomorphs after detrital gypsum grains. C) Wave ripples in arenites (arrows). D) Wave-ripple cross-laminated arenite (black arrow) interbedded with parallel-laminated limestone and graded-laminated limestone.

1994), and occurs even in the absence of runoff discharges (Chao et al. 2008).

Graded-laminated limestones (Facies 2) of the Valdeprado Fm contain fine-grained detrital gypsum, ostracodes, quartz, mica, and carbonate mud. These components are the same as those observed in the facies interbedded with the graded laminae (Facies 1, 3, 5, and 6, Fig. 3, Table 1). Thus, graded-laminated limestone could have been formed as a result of resuspension of previously deposited sediment while this was still soft, due to wind-induced currents and waves or storms. Nevertheless, deposition of this resuspended material could have occurred in both deep or shallow areas, because accumulation areas for resuspended particles are not necessarily determined by the water depth, and sediment can accumulate even in areas less than $1 \mathrm{~m}$ deep (Lövsedt and Bengtsson 2008).

The presence of mudcracks at the top of some graded laminae of the Valdeprado Formation is very useful for their interpretation in terms of depth. These mudcracks display features indicating that they were formed by desiccation processes. Polygonal patterns, upward curling of the cracked beds, and v-shapes tapering downward are typical of desiccation mudcracks (Plummer and Gostin 1981; Collinson and Thompson 1982; Demicco and Hardie 1994; Tanner 1998; Weinberger 2001). These features are distinguishable from cracks formed as a result of other mechanisms, such as synaeresis or diastasis cracks. For example, synaeresis cracks show irregular or radiating patterns, and they are parallel-sided, lenticular, or v-shaped and tapering downward or upward when viewed normal to bedding. Moreover, layers cracked by synaeresis processes do not typically exhibit upward curling; rather, they are tabular or biconcave (Plummer and Gostin 1981; Collinson and Thompson 1982; Pratt 1998). On the other hand, diastasis crack patterns include complete polygons, but linear alignment of unconnected cracks and arcuate to curlicue configurations as well (Cowan and James 1992). They can be uniformly open top to bottom, tapered up or tapered down, or dilated only along part of their length. Numerous firm sediment deformation structures, including postdepositional normal faults and slides, are associated with large diastasis cracks (Cowan and James 1992). Finally, the most useful feature for distinguishing desiccation cracks from 

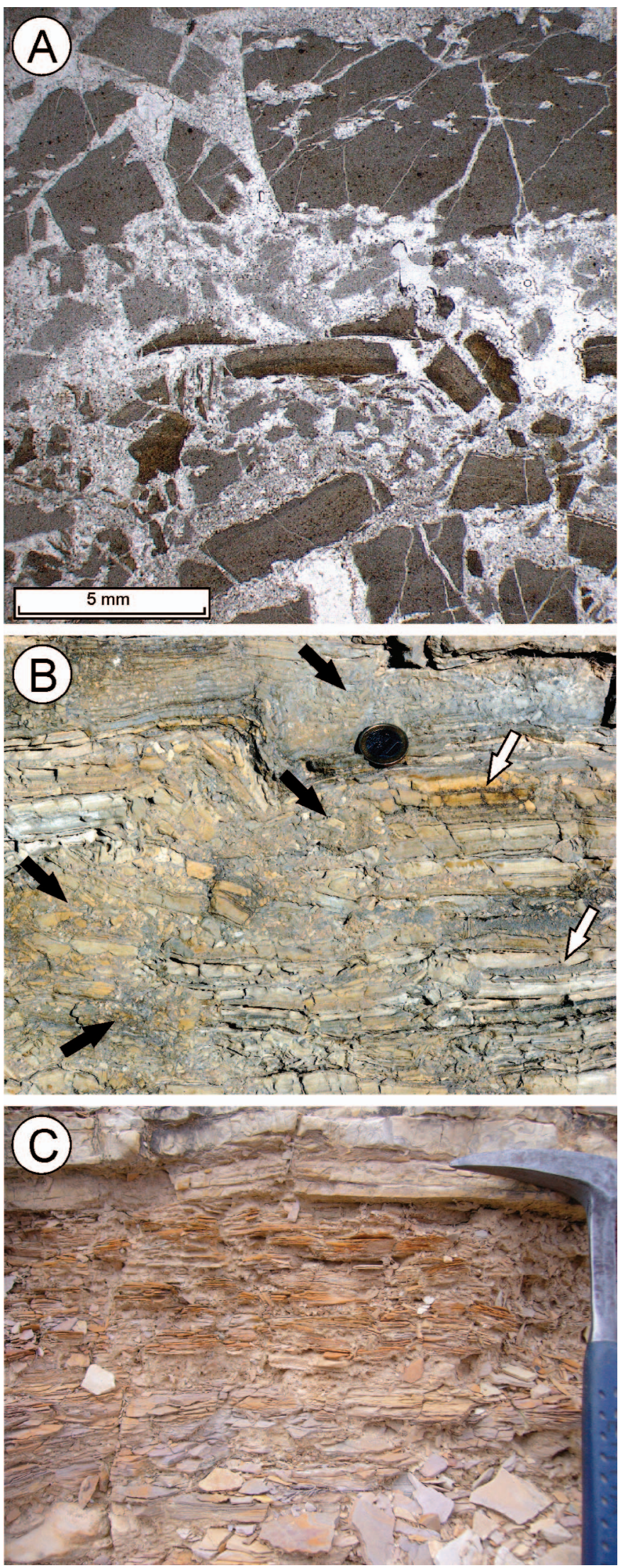

diastasis cracks is the infill. In diastasis cracks, infill is introduced from either above, below, and/or laterally, and the infill is not stratified or multigenerational (Cowan and James 1992). The mudcracks of the Valdeprado Formation display stratified infills made up of silty carbonate and thin laminae of ostracode wackestone deposited from above, which are characteristic of desiccation cracks (Collinson and Thompson 1982; Demicco and Hardie 1994). Although similar infills may occur in synaeresis cracks, material derived from below is also typical (Plummer and Gostin 1981; Pratt 1998). Moreover, the presence of evaporites within the cracks is a common feature in subaerial cracks (Hardie et al. 1978; Renaut and Long 1989; Paik and Kim 1998).

The rectangular pseudomorphs associated with the mudcracks in this unit are interpreted as originally anhydrite crystals due to their welldeveloped orthorhombic morphology. We interpret that the precipitation of anhydrite within the cracks occurred as the mud lost moisture and shrinkage cracks were formed. These mudcracks likely were more permeable areas that acted as conduits for sediment pore water flow caused by evaporative pumping (Hsü and Siegenthaler 1969), and anhydrite crystals precipitated within them slightly displacing the matrix around them (Fig. 11). The development of anhydrite instead of gypsum is a consequence of higher temperatures and/or higher salinities of the brine (Hardie 1967; Ortí 2010a), which may be achieved more easily at desiccation, and it is also a clue that precipitation occurred above the water table, as seen in modern sabkhas (Warren 1991, 2006; Alsharhan and Kendall 2003). The precipitation of evaporites associated with desiccation cracks has been described in mudflat environments (Hardie et al. 1978), and is equivalent to the halite efflorescences that develop in polygonal cracks of saline pans in response to evaporation of the subsurface brine drawn up the cracks (Lowenstein and Hardie 1985; Pakzad and Kulke 2007). Halite precipitating in polygon cracks of saline pans commonly is removed and dissolved by the next flooding event. Considering the lower solubility of sulfates, however, the anhydrite precipitated in the mudcracks of the Valdeprado Formation may have remained undissolved after the subsequent freshwater inflow.

The fact that in two stratigraphic intervals (Fig. 3) the mudcracks are present in successive laminae (Fig. 7A, B) indicates that desiccation occurred frequently during these intervals, and water depth during sediment deposition was very shallow (around a few decimeters) in order to desiccate completely repeatedly. Although mudcracked layers are scarce in the rest of the succession (Fig. 3), the sedimentary features of all the graded laminae are identical independently of the presence or absence of mudcracks, suggesting that all of the graded laminae, whether showing evidence of desiccation or not, were deposited as a result of the same depositional processes, probably under shallow-water conditions. Thus, the graded-laminated limestone facies was likely deposited in environments less than a few meters deep as a result of sediment resuspension and subsequent deposition. Afterwards, the water slowly evaporated, allowing precipitation of displacive sulfates, and only when the water evaporated completely did desiccation cracks form.

Parallel-laminated limestone and graded-laminated limestone are interbedded sporadically with current-ripple and wave-ripple crosslaminated arenites (Facies 3) made up of intrabasinal particles (detrital

$\leftarrow$

FIG. 9.-A) Thin-section photomicrograph of a carbonate breccia. The fragments are similar to the carbonate mudstone with dispersed pseudomorphs after lenticular gypsum in parallel-laminated limestone facies (Facies 1), and the matrix is composed by pseudosparitic calcite, which replaces the original sulfates. B) Carbonate breccias associated with folds. Note that displacement of fragments varies from complete disruption close to the fold (black arrows) to little displacement a few centimeters away from the fold (white arrows). C) Ochre to purple-colored, fissile shales. 

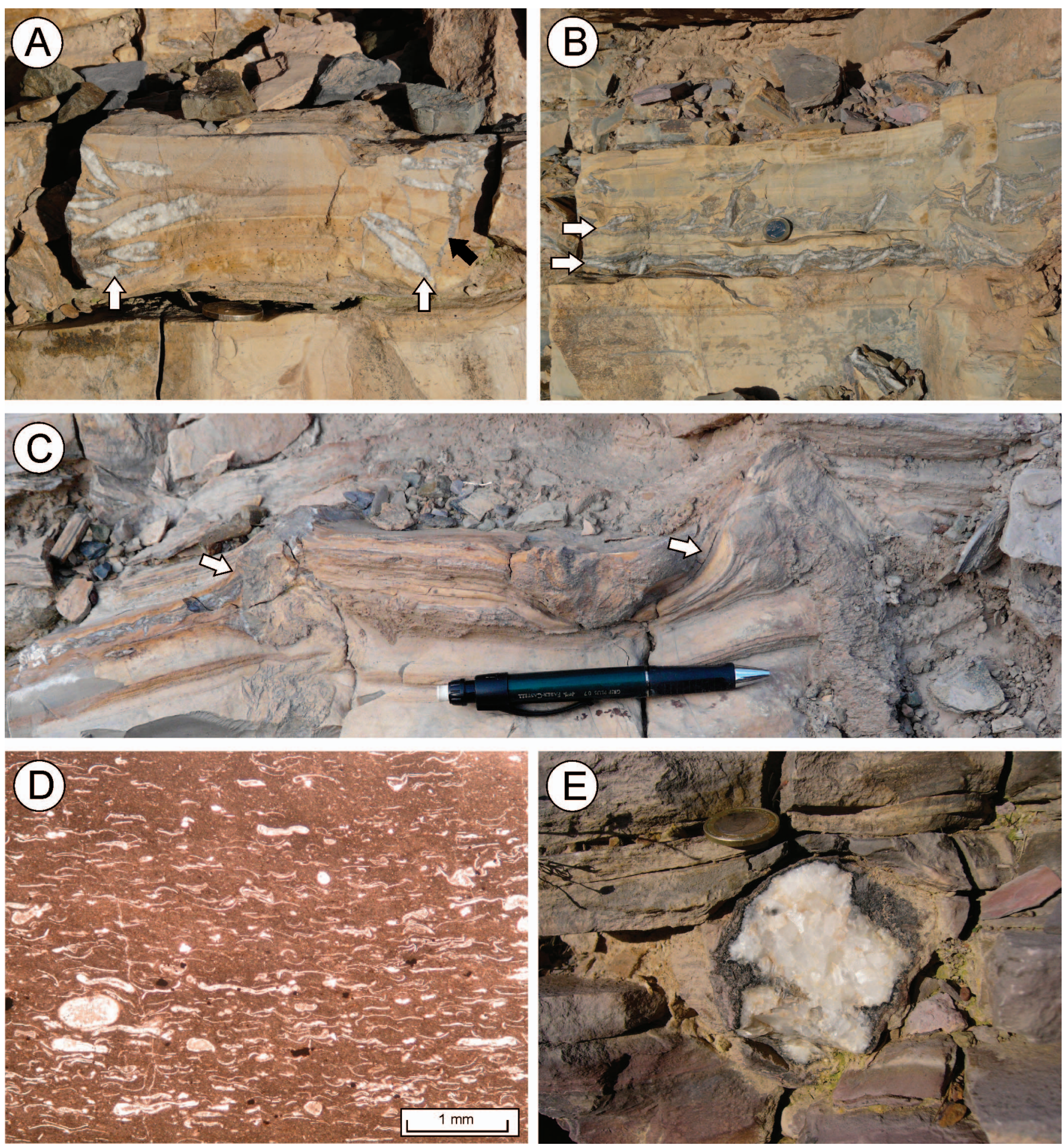

FIG. 10.-A) Outcrop photo of ostracode mudstone to wackestone with vertically aligned centimeter-size pseudomorphs after gypsum (white arrows) associated with mudcracks (black arrow). B) Outcrop photo of ostracode mudstone to wackestone with centimeter-size pseudomorphs after gypsum. The pseudomorphs grew displacively in horizontal levels that coincide with contacts between laminae. C) Tepee structures in ostracode mudstone to wackestone with centimeter-size pseudomorphs after gypsum. D) Thin-section photomicrograph of ostracode wackestone to packstone. E) Anhydrite nodule replaced by calcite, quartz, and dolomite within ostracode and gastropod wackestone to packstone.

gypsum grains replaced by calcite, peloids, and ostracode fragments). The presence of cross-laminated arenites may be another indicator of depth. Although current ripples may form in waters of any depth, in lakes they are more common in shallower areas (Reineck and Singh 1973). Wave ripples do form mostly in shallow waters (Allen 1982; Nichols 2009), and in lakes they are restricted to water depths of only a few meters under normal conditions, or up to 10-15 m during storms (Allen 1982; Håkanson 2007). Gentle dips of the foreset laminae and small wave 


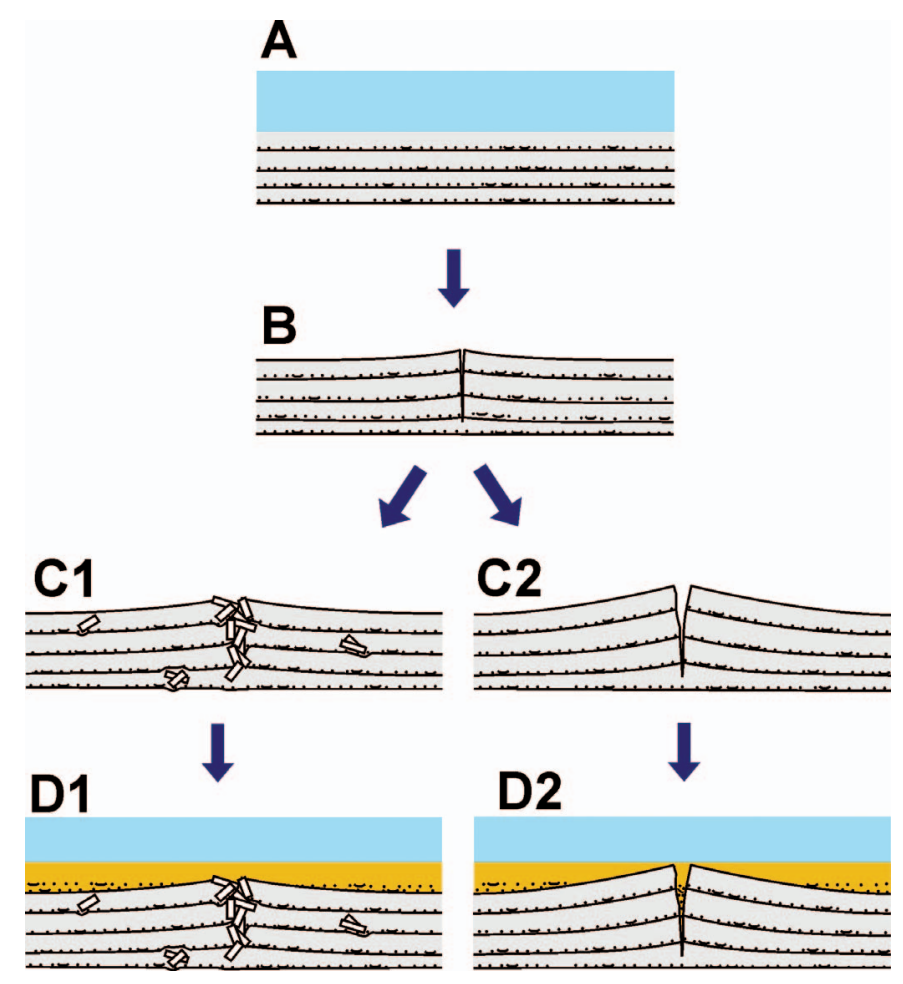

FIG. 11.-Diagram of the development of the two types of desiccation mudcracks observed in the laminated carbonates of the Valdeprado Formation. A) Deposition of graded-laminated limestone. B) Complete evaporation of the water, loss of moisture within the mud, and beginning of the shrinkage of the mud. C1) Precipitation of intrasediment anhydrites within the cracks. C2) Continuation of shrinkage process. D1) New water input and deposition of a new lamina. D2) New water input and deposition of a new lamina. The mudcrack is filled with new material from above, and the infilling is stratified.

ripples, as those observed in the study area, are also indicative of shallow waters (Reineck and Singh 1973). In evaporitic settings, gypsarenite showing cross-lamination is characteristic of shallow environments in the photic zone (Schreiber et al. 1976; Kendall 1992; Warren 2006). Given the preponderance of evidence, the environment in which these sediments were deposited is interpreted to be above the wave-base depth and affected by currents.

In the upper part of the formation (Fig. 3), parallel-laminated limestone and graded-laminated limestone are interbedded with ostracode mudstone to wackestone with centimeter-size pseudomorphs after displacive gypsum (Facies 6). The abundance of mudcracks and tepees in Facies 6 indicates that it was formed in a commonly desiccated, ephemeral environment. Moreover, the large pseudomorphs after displacive lenticular gypsum abundant in this facies resemble examples described from saline mudflats or ephemeral lakes (Smoot and Lowenstein 1991; Rouchy et al. 1993; Gibert et al. 2007). On the basis of these observations and interpretations, this facies is interpreted as deposited in a carbonate mudflat affected by water-level fluctuations. During flooding, the area was covered by water, which allowed carbonate accumulation, and afterwards the area was subaerially exposed due to water evaporation, which allowed the development of displacive gypsum, mudcracks, and tepees. The interlayering of this facies and parallellaminated and graded-laminated limestones reinforces the hypothesis that these two latter facies were deposited under shallow-water conditions.

Finally, deposition of shale layers (Facies 5), which are interbedded with the rest of the facies throughout the stratigraphic section (Fig. 3), was probably related to siliciclastic discharges coming from the adjacent western areas of the basin, where siliciciclasic sandy-muddy flats developed (Gómez-Fernández and Meléndez 1994; Meléndez and Gómez-Fernández 2000; Quijada et al. 2010).

The uppermost $13 \mathrm{~m}$ of the formation (Fig. 3) represents a change in the sedimentary environment, in that the parallel-laminated limestones (Facies 1), graded-laminated limestones (Facies 2), cross-laminated arenites (Facies 3), carbonate breccias (Facies 4), and ostracode mudstone to wackestone with large pseudomorphs after gypsum (Facies 6) are not present. These uppermost $13 \mathrm{~m}$ of the formation are made up of ostracode and gastropod wackestone to packstone interbedded with shale. The larger proportion of fossils in this facies (relative to the rest of limestone facies in the formation) and the numerous shale interbeds suggest frequent freshwater input, which could allow more fauna to inhabit these water bodies. The presence of rare calcite, quartz, and dolomite nodules, interpreted as pseudomorphs after anhydrite nodules due to the acicular habits of the original crystals that made up the nodules (Ciarapica et al. 1985; Ortí and Rosell 1997), indicates that the saturation in calcium sulfate was sporadically high enough to precipitate displacive anhydrite within the matrix. These rare salinity increases were probably caused by evaporation between successive water discharges.

Depositional geometry and lateral relationships of the laminated carbonates of the Valdeprado Formation give further information about their depositional depth. The fact that laminated carbonate layers are parallel along the outcropping area, and the absence of gravity structures, such as slump structures or slide masses, suggests no marked gradients in the basin (Fig. 4B, C). Moreover, in the western part of the basin (Fig. 4C), the laminated carbonates pass laterally into, and are interbedded with, siliciclastic sediments developed in sandy-muddy flats (displaying ubiquitous desiccation cracks and vertebrate footprints) without any other facies in between. This relationship suggests that these siliciclastic deposits discharged into the shallow water bodies, and depth of deposition did not vary more than a few meters from the siliciclastic area to the carbonate-sulfate environment, which in turn was intermittently desiccated as well. All of these features, plus the fact that the same carbonate laminated facies were developed along the 40-km-long outcropping area, and that they display desiccation mudcracks tens of kilometers away from the siliciclastic deposits, suggest sedimentation in broad, shallow, flat-bottomed environments.

In light of all these considerations, the laminated carbonates of the Valdeprado Formation are interpreted as deposited in shallow, perennial carbonate-sulfate water bodies and their peripheral mudflats, developed in a broad, flat-bottomed basin (Fig. 12). The term shallow perennial lakes is used in the sense of Schubel and Lowenstein (1997), who define them as less than 10-m-deep lakes that persist for tens to thousands of years. Sedimentation in these shallow water bodies was strongly controlled by alternation of flooding and evaporation, which caused salinity variations and alternation of deposition of carbonate and sulfate laminae when calm conditions prevailed, as seen in modern and ancient shallow saline lakes (Hardie et al. 1978; Smoot and Lowenstein 1991; Benison and Goldstein 2001). As the water bodies were as much as a few meters deep, currents and waves affected episodically the sediment, and facilitated formation of thin rippled laminae and deposition of graded laminae in response to sediment resuspension, a process that commonly occurs in modern shallow environments (Bengtsson and Hellström 1992; Jin and Sun 2007; Kelderman et al. 2012; Evans 1994; Chao et al. 2008; Lövsedt and Bengtsson 2008). The areas around these water bodies were occupied by carbonate mudflats disrupted by displacive gypsums, desiccation cracks, and tepees, which are comparable to modern and ancient saline mudflats (Bowler 1986; Salvany et al. 1994; Sanz-Montero et al. 2008). Considering the very flat bottom of these settings, decimeterscale or few-meters-scale drawdown in water level led to exposure of very broad areas and development of mudcracks in the subaerially exposed 

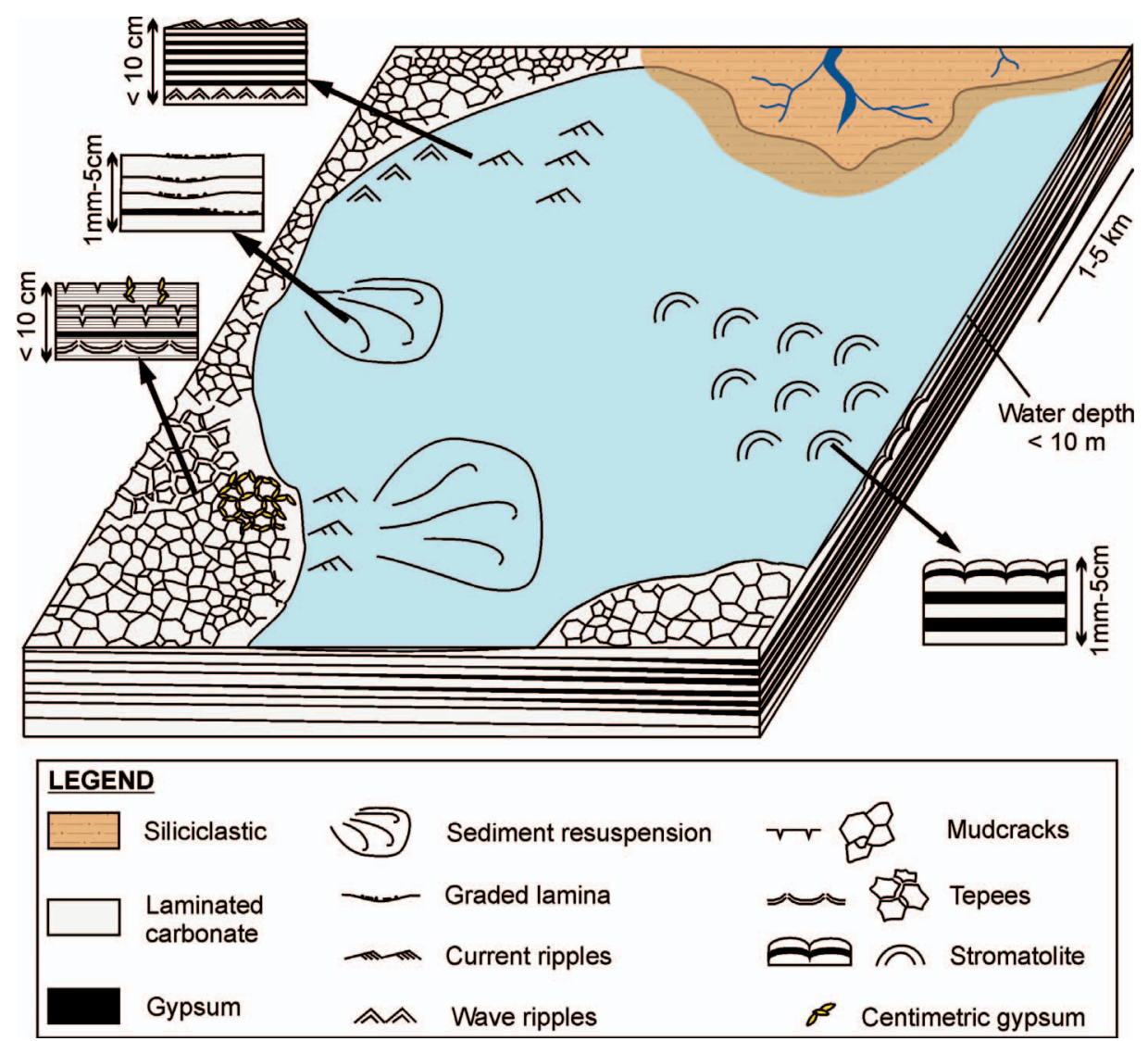

FIG. 12.--Schematic diagram showing depositional framework for the shallow, carbonatesulfate water bodies developed in the Valdeprado Formation (vertical scale is exaggerated relative to horizontal scale, and the vertical scale of the sediments is exaggerated relative to the water depth in order to represent the lamination). Parallel-laminated limestone can be formed in any area of the water body. Graded-laminated limestone is formed where the bottom is affected by sediment-charged currents caused by sediment resuspension. Current ripples and wave ripples occur in areas where unidirectional currents or waves affect the sediment, respectively. Mudcracks, tepees, and centimeter-size lenticular gypsum develop in desiccated areas. Considering the very flat bottom, decimeterscale or few-meters-scale changes in the water depth lead to flooding or exposure of very broad areas. Siliciclastic discharges come into the water body from adjacent, siliciclastic, sandymuddy flats. sediments, which is not rare in shallow saline lakes (e.g., Smoot and Lowenstein 1991; Schubel and Lowenstein 1997).

The Valdeprado Formation thus provides an example of an ancient deposit dominated by laminations, which is not explained by deposition in a deep anoxic lake bottom unaffected by currents, but it was probably formed under shallow-water conditions. This study shows that the abundance of laminations and the absence of subaerial exposure evidence can lead to a false impression of deposition in deep-water settings. Although the presence of desiccation cracks in some stratigraphic intervals of the Valdeprado Formation is very helpful to demonstrate the shallowness of the water bodies, this example also illustrates that the absence or scarcity of evidence of subaerial exposure cannot be used in isolation to interpret laminated deposits as formed in deep-water lakes.

\section{CONCLUSIONS}

The combined analysis of sedimentary features, facies relationships, and depositional geometries of the 900-m-thick laminated carbonate deposits of the Valdeprado Formation indicates that they were deposited in shallow, perennial carbonate-sulfate water bodies and their peripheral mudflats. Moreover, this study shows that lacustrine sedimentary rocks should not be interpreted as formed in deep lakes based solely on the abundance of lamination and the absence or scarcity of evidence of subaerial exposure.

The two most abundant facies in this formation, parallel-laminated limestone and graded-laminated limestone, were deposited as the result of salinity fluctuations driven by alternating flooding and evaporation, and sediment resuspension processes, respectively. These facies can be formed in both shallow and deep water bodies, and as a consequence, additional criteria are necessary to interpret their depth of deposition. The applied criteria for interpreting the Valdeprado Formation, and potentially useful for other successions in the geological record, are: 1) presence of desiccation mudcracks, which are scarce in most of the stratigraphic section except in two stratigraphic intervals that contain up to 25 mudcracked laminae per meter of deposit. The absence or scarcity of desiccation mudcracks should be carefully evaluated, and not directly interpreted as a proof of deposition in a deep lake; 2) association of parallel-laminated limestone and graded-laminated limestone with crosslaminated arenites; 3) interbedding of parallel-laminated limestone and graded-laminated limestone with limestone displaying centimeter-size pseudomorphs after gypsum, tepees, and desiccation cracks; 4) depositional geometries showing continuous, parallel beds and no marked gradients along kilometers; 5) presence of the same laminated carbonate facies along tens of kilometers, and direct interbedding and lateral change with siliciclastic sandy-muddy flat deposits.

\section{ACKNOWLEDGMENTS}

This work was funded by the Spanish Department of Research, Development and Innovation projects CGL2008-01648/BTE and CGL201122709, the "Sedimentary Basin Analysis" Research Group of the Complutense University of Madrid-Madrid Community, and a Spanish Department of Education FPU scholarship. The authors would like to thank K. Benison, B.C. Schreiber, S. Lugli, and G. Rankey for their careful reviews, E. Gierlowski-Kordesch for her comments on an earlier version of the manuscript, and F. Ortí for helpful scientific discussion in the field and in the laboratory. We also thank the staff of the Department of Stratigraphy of the Complutense University of Madrid for their technical support.

\section{REFERENCES}

Allen, J.R.L., 1982, Sedimentary Structures; Their Character and Physical Basis, vol. 1: Amsterdam, Elsevier, 593 p

Alsharhan, A.S., and Kendall, C.G.St.C., 2003, Holocene coastal carbonates and evaporites of the southern Arabian gulf and their ancient analogues: Earth-Science Reviews, v. 61, p. 191-243. 
Anderson, R.Y., And Dean, W.E., 1988, Lacustrine varve formation through time: Palaeogeography, Palaeoclimatology, Palaeoecology, v. 62, p. 215-235.

Andrews, S.D., Trewin, N.H., Hartley, A.J., and Weedon, G.P., 2010, Solar variance recorded in lacustrine deposits from the Devonian and Proterozoic of Scotland Geological Society of London, Journal, v. 167, p. 847-856.

Arribas, J., Alonso, A., Mas, R., Tortosa, A., Rodas, M., Barrenechea, J.F., Alonso-Azcárate, J., And Artigas, R., 2003, Sandstone petrography of continenta depositional sequences of an intraplate rift basin: Western Cameros Basin (North Spain): Journal of Sedimentary Research, v. 73, p. 309-327.

Bengtsson, L., AND Hellström, T., 1992, Wind-induced resuspension in a small shallow lake: Hydrobiologia, v. 241, p. 163-172.

Benison, K.C., And Goldstern, R.H., 2001, Evaporites and siliciclastics of the Permian Nippewalla Group of Kansas, U.S.A.: a case for non-marine deposition in saline lakes and saline pans: Sedimentology, v. 48, p. 165-188.

BowLER, J.M., 1986, Spatial variability and hydrologic evolution of Australian lake basins: analogue for Pleistocene hydrologic change and evaporite formation: Palaeogeography, Palaeoclimatology, Palaeoecology, v. 54, p. 21-41.

Buscalioni, A.D., And Fregenal-Martinez, M.A., 2010, A holistic approach to the palaeoecology of Las Hoyas Konservat-Lagerstätte (La Huérguina Formation, Lower Cretaceous, Iberian Ranges, Spain): Journal of Iberian Geology, v. 36, p. 297-326.

Chao, X., Jia, Y., Shields, F.D., Jr., Wang, S.S.Y., And Cooper, C.M., 2008, Threedimensional numerical modeling of cohesive sediment transport and wind wave impact in a shallow oxbow lake: Advances in Water Resources, v. 31, p. 1004-1014.

Ciarapica, G.L., Passeri, L., And Schreiber, B.C., 1985, Una proposta di classificazione delle evaporiti solfatiche: Geologica Romana, v. 24, p. 219-232

Collinson, J.D., And Thompson, D.B., 1982, Sedimentary Structures: London, George Allen \& Unwin, 194 p.

Corella, J.P., El Amrani, A., Sigró, J., Morellón, M., Rico, E., and Valero-Garcés, B.L., 2011a, Recent evolution of Lake Arreo, northern Spain: influences of land use change and climate: Journal of Paleolimnology, v. 46, p. 469-485.

Corella, J.P., Moreno, A., Morellón, M., Rull, V., Giralt, S., Rico, M.T., PérezSanz, A., and Valero-Garcés, B.L., 2011b, Climate and human impact on a meromictic lake during the last 6,000 years (Montcortès Lake, Central Pyrenees, Spain): Journal of Paleolimnology, v. 46, p. 351-367.

CowAN, C.A., AND JAMES, N.P., 1992, Diastasis cracks: mechanically generated synaeresis-like cracks in Upper Cambrian shallow water oolite and ribbon carbonates: Sedimentology, v. 39, p. 1101-1118.

Demicco, R.V., And Hardie, L.A., 1994, Sedimentary Structures and Early Diagenetic Features of Shallow Marine Carbonate Deposits: SEPM, Atlas Series, 265 p.

Dickson, J.A.D., 1966, Carbonate identification and genesis as revealed by staining: Journal of Sedimentary Petrology, v. 36, p. 491-505.

Eugster, H.P., AND Hardie, L.A., 1975, Sedimentation in an ancient playa-lake complex: The Wilkins Peak Member of the Green River Formation of Wyoming Geological Society of America, Bulletin, v. 86, p. 319-334.

Evans, R.D., 1994, Empirical evidence of the importance of sediment resuspension in lakes: Hydrobiologia, v. 284, p. 5-12.

Finkelstein, D.B., Hay, R.L., and Altaner, S.P., 1999, Origin and diagenesis of lacustrine sediments, upper Oligocene Creed Formation, southwestern Colorado: Geological Society of America, Bulletin, v. 111, p. 1175-1191.

FlügEL, E., 2010, Microfacies of Carbonate Rocks: Analysis, Interpretation and Application: Heidelberg, Springer, 984 p.

Fraser, N.C., Grimaldi, D.A., Olsen, P.E., And Axsmith, B., 1996, A Triassic Lagerstätte from eastern North America: Nature, v. 380, p. 615-619.

Fregenal-Martínez, M.A., And MelÉndez, N., 2010, Lagos y sistemas lacustres, in Arche, A., ed., Sedimentología. Del Proceso Físico a la Cuenca Sedimentaria: Madrid, Consejo Superior de Investigaciones Científicas, p. 299-395.

Freytet, P., AND Verrecchia, E.P., 2002, Lacustrine and palustrine carbonate petrography: an overview: Journal of Paleolimnology, v. 27, p. 221-237.

Gibert, L., Ortí, F., AND Rosell, L., 2007, Plio-Pleistocene lacustrine evaporites of the Baza Basin (Betic Chain, SE Spain): Sedimentary Geology, v. 200, p. 89-116.

GierlowsKI-Kordesch, E.H., 2010, Lacustrine carbonates, in Alonso-Zarza, A.M., and Tanner, L.H., eds., Carbonates in Continental Settings: Facies, Environments, and Processes: Amsterdam, Elsevier, p. 1-101.

Gierlowski-Kordesch, E., ANd Rust, B., 1994, The Jurassic East Berlin Formation, Hartford Basin, Newark Supergroup (Connecticut and Massachusetts): a saline lakeplaya-alluvial plain system, in Renant, R.W., and Last, W.M., eds., Sedimentology and Geochemistry of Modern and Ancient Saline Lakes: SEPM, Special Publication 50 , p. $250-265$.

Glenn, C.R., And Kelts, K., 1991, Sedimentary rhythms in lake deposits, in Einsele, G., Ricken, W., and Seilacher, A., eds., Cycles and Events in Stratigraphy: New York, Springer-Verlag, p. 188-221.

Gómez-Fernández, J.C., And Meléndez, N., 1994, Estratigrafía de la "Cuenca de Cameros" (Cordillera Ibérica Noroccidental, N de España) durante el tránsito Jurásico-Cretácico: Sociedad Geológica de España, Revista, v. 7, p. 121-139.

Grabau, A.W., 1904, On the classification of sedimentary rocks: The American Geologist, v. 33, p. 228-247.

Grabau, A.W., 1913, Principles of Stratigraphy: New York, A.G. Seiler and Company, $1185 \mathrm{p}$.

GuimerÀ, J., Alonso, A., And Mas, J.R., 1995, Inversion of an extensional-ramp basin by a newly formed thrust: the Cameros Basin (N Spain), in Buchanan, J.G., and Buchanan, P.G., eds., Basin Inversion: Geological Society of London, Special Publication 88, p. 433-453.
Guiraud, M., And Seguret, M., 1985, A releasing solitary overstep model for the Late Jurassic-Early Cretaceous (Wealdian) Soria strike-slip basin (Northern Spain), in Biddle, K.T., and Christie-Blick, N., eds., Strike Slip Deformation, Basin Formation and Sedimentation: SEPM, Special Publication 37, p. 159-175.

HaKala, A., 2004, Meromixis as a part of lake evolution-observations and a revised classification of true meromictic lakes in Finland: Boreal Environment Research, v. 9, p. $37-53$.

HÅKanson, L., 2007, Lake environments, in Perry, C., and Taylor, K., eds., Environmental Sedimentology: Malden, Massachusetts, Blackwell Publishing, p. 109-143.

HARDIE, L.A., 1967, The gypsum-anhydrite equilibrium at one atmosphere pressure: The American Mineralogist, v. 52, p. 171-200.

Hardie, L.A., Smoot, J.P., And Eugster, H.P., 1978, Saline lakes and their deposits: a sedimentological approach, in Matter, A., and Tucker, M.E., eds., Modern and Ancient Lake Sediments: International Association of Sedimentologists, Special Publication 2, p. 7-41.

Helman, M.L., And Schreiber, B.C., 1985, Permian evaporite deposits of the Italian Alps (Dolomites): the development of unusual and significant fabrics, in Schreiber, B.C., and Harner, L., eds., Sixth International Symposium on Salt (1983) v. 1: Alexandria, Virginia, Salt Institute, p. 57-66.

Hernández, N., Pascual, C., Latorre, P., and Sanz, E., 2005-2006, Contribución de los yacimientos de icnitas sorianos al registro general de Cameros: Zubía, v. 23-24, p. 79-120.

Hsü, K.J., and Siegenthaler, C., 1969, Preliminary experiments on hydrodynamic movement induced by evaporation and their bearing on the dolomite problem: Sedimentology, v. 12, p. 11-25.

Jin, K.-R., AND Sun, D., 2007, Sediment resuspension and hydrodynamics in Lake Okeechobee during the late summer: Journal of Engineering Mechanics, v. 133, p. 899-910.

Kelderman, P., Ang'weya, R.O., De Rozari, P., and Vijverberg, T., 2012, Sediment characteristics and wind-induced sediment dynamics in shallow Lake Markermeer, the Netherlands: Aquatic Sciences, v. 74, p. 301-313.

Kelts, K.R., And Hsü, K.J., 1978, Freshwater carbonate sedimentation, in Lerman, A., ed., Lakes: Geology, Chemistry, Physics: New York, Springer-Verlag, p. 295-323.

KemP, A.E.S., 1996, Laminated sediments as palaeo-indicators, in Kemp, A.E.S., ed., Palaeoclimatology and Palaeoceanography from Laminated Sediments: Geological Society of London, Special Publication 88, p. vii-xii.

Kendall, A.C., 1992, Evaporites, in Walker, R.G., and James, N.P., eds., Facies Models: Response to Sea Level Change: St. John's, Newfoundland, Geological Association of Canada, p. 375-409.

Kroes, H.W., 1986, Restoration of shallow lake ecosystems, with emphasis on Loosdrecht lakes: Hydrobiological Bulletin, v. 20, p. 5-7.

LAmbert, A., AND Hsü, K.J., 1979, Non-annual cycles of varve-like sedimentation in Walensee, Switzerland: Sedimentology, v. 26, p. 453-461.

LAST, W.M., AND VANCE, R.E., 1997, Bedding characteristics of Holocene sediments from salt lakes of the northern Great Plains, Western Canada: Journal of Paleolimnology, v. 17, p. 297-318.

Liutkus, C.M., Beard, J.S., Frases, N.C., and Ragland, P.C., 2010, Use of fine-scale stratigraphy and chemostratigraphy to evaluate conditions of deposition and preservation of a Triassic Lagerstätte, south-central Virginia: Journal of Paleolimnology, v. 44, p. 645-666.

Lövstedt, C.B., AND Bengtsson, L., 2008, The role of non-prevailing wind direction on resuspension and redistribution of sediments in a shallow lake: Aquatic Sciences, v. 70 , p. 304-313.

Lowenstein, T.K., and Hardie, L.A., 1985, Criteria for the recognition of salt-pan evaporites: Sedimentology, v. 32, p. 627-644.

LudLam, S.D., 1974, Fayetteville Green Lake, New York. 6. The role of turbidity currents in lake sedimentation: Limnology and Oceanography, v. 19, p. 656-664.

Lugli, S., 2001, Timing of post-depositional events in the Burano Formation of the Secchia valley (Upper Triassic, Northern Apennines), clues from gypsum-anhydrite transitions and carbonate metasomatism: Sedimentary Geology, v. 140, p. 107-122.

MAgEe, J.W., 1991, Late Quaternary lacustrine, groundwater, aeolian and pedogenic gypsum in the Prungle Lakes, southeastern Australia: Palaeogeography, Palaeoclimatology, Palaeoecology, v. 84, p. 3-42.

Makhlouf, I.M., And Aziz El-Hadad, A., 2006, Depositional environments and facies of the Late Triassic Abu Ruweis Formation, Jordan: Journal of Asian Earth Sciences, v. 28 , p. $372-384$.

Martín-Closas, C., 1989, Els caròfits del Cretaci inferior de les conques perifèriques del bloc de l'Ebre [unpublished Ph.D. Thesis]: University of Barcelona, Spain, 581 p.

Mas, J.R., Alonso, A., And GuimerÀ, J., 1993, Evolución tectonosedimentaria de una cuenca extensional intraplaca: La cuenca finijurásica-eocretácica de Los Cameros (La Rioja-Soria): Sociedad Geológica de España, Revista, v. 6, p. 129-144.

Mas, R., Benito, M.I., Arribas, J., Serrano, A., Guimerà, J., Alonso, A., and AlonsoAzcárate, J., 2002, La Cuenca de Cameros: desde la extensión finijurásicaeocretácica a la inversión terciaria-implicaciones en la exploración de hidrocarburos: Zubía, v. 14, p. 9-64.

Mas, R., García, A., Salas, R., Meléndez, A., Alonso, A., Aurell, M., Bádenas, B. Benito, M.I., Carenas, B., Garcia-Hidalgo, J.F., Gil, J., and Segura, M., 2004 Segunda fase de rifting: Jurásico Superior-Cretácico Inferior, in Vera, J.A., ed., Geología de España: Madrid, Sociedad Geológica de España, Instituto Geológico y Minero de España, p. 503-510. 
Meléndez, N., and Gómez-Fernández, J.C., 2000, Continental deposits of the eastern Cameros Basin (northern Spain) during Tithonian-Berriasian time, in GierlowskiKordesch, E., and Kelts, K.R., eds., Lake Basins through Space and Time: American Association of Petroleum Geologists, Studies in Geology 46, p. 263-278.

Mingram, J., 1998, Laminated Eocene maar-lake sediments from Eckfeld (Eifel region, Germany) and their short-term periodicities: Palaeogeography, Palaeoclimatology, Palaeoecology, v. 140, p. 289-305.

Mitchell, R.W., 1985, Comparative sedimentology of shelf carbonates of the Middle Ordovician St. Paul Group, Central Appalachians: Sedimentary Geology, v. 43, p. $1-41$.

Moratalla, J.J., And Hernán, J., 2010, Probable palaeogeographic influences of the Lower Cretaceous Iberian rifting phase in the Eastern Cameros Basin (Spain) on dinosaur trackway orientations: Palaeogeography, Palaeoclimatology, Palaeoecology, v. 295 , p. $116-130$

Müller, W.H., AND BRIEgel, U., 1978, The rheological behaviour of polycrystalline anhydrite: Eclogae Geologicae Helvetiae, v. 71, p. 397-407.

Nichols, G., 2009, Sedimentology and Stratigraphy: Oxford, U.K., Wiley-Blackwell, $419 \mathrm{p}$.

Olsen, P.E., 1986, A 40-million year lake record of early Mesozoic orbital climatic forcing: Science, v. 234, p. 842-848.

OrTí, F., 2010a, Evaporitas: introducción a la sedimentología evaporítica, in Arche, A. ed., Sedimentología. Del Proceso Físico a la Cuenca Sedimentaria: Madrid, Consejo Superior de Investigaciones Científicas, p. 675-769.

OrTí, F., 2010b, Evaporitas: formaciones marinas y continentales. Algunos ejemplos, in Arche, A., ed., Sedimentología. Del Proceso Físico a la Cuenca Sedimentaria: Madrid, Consejo Superior de Investigaciones Científicas, p. 771-838.

OrTí, F., 2011, Selenite facies in marine evaporites: a review, in Kendall, C.G.St.C., and Alsharhan, A.S., eds., Quaternary carbonate and evaporite sedimentary facies and their ancient analogues: International Association of Sedimentologists, Special Publication 43, p. 431-464.

Ortí, F., AND Rosell, L., 1997, Sulfatos evaporíticos de interés petrológico, in Melgarejo, J.C., ed., Atlas de asociaciones minerales en lámina delgada: Barcelona, Fundació Folch, p. 210-235.

PAIK, I.S., AND KIM, H.J., 1998, Subaerial lenticular cracks in Cretaceous lacustrine deposits, Korea: Journal of Sedimentary Research, v. 68, p. 80-87.

PaIK, I.S., AND KIm, H.J., 2006, Playa lake and sheetflood deposits of the Upper Cretaceous Jindong Formation, Korea: Occurrences and palaeoenvironments: Sedimentary Geology, v. 187, p. 83-103.

PakZaD, H.R., AND KulKe, H., 2007, Geomorphological features in the Gavkhoni playa lake, SE Esfahan, Iran: Carbonates and Evaporites, v. 22, p. 1-5.

Pietras, J.T., AND Carroll, A.R., 2006, High-resolution stratigraphy of an underfilled lake basin: Wilkins Peak Member, Eocene Green River Formation, Wyoming, U.S.A.: Journal of Sedimentary Research, v. 76, p. 1197-1214.

Platt, N.H., AND Wright, V.P., 1991, Lacustrine carbonates: facies models, facies distributions and hydrocarbon aspects, in Anadón, P., Cabrera, L., and Kelts, K., eds., Lacustrine Facies Analysis: International Association of Sedimentologists, Special Publication 13, p. 57-74.

Plummer, P.S., AND Gostin, V.A., 1981, Shrinkage cracks: desiccation or synaeresis?: Journal of Sedimentary Petrology, v. 51, p. 1147-1156.

Pomar, L., AND Hallock, P., 2008, Carbonate factories: a conundrum in sedimentary geology: Earth-Science Reviews, v. 87, p. 134-169.

PRATT, B.R., 1998, Syneresis cracks: subaqueous shrinkage in argillaceous sediments caused by earthquake-induced dewatering: Sedimentary Geology, v. 117, p. 1-10.

Quijada, I.E., Suárez-González, P., Bentto, M.I., Mas, J.R., And Alonso, A., 2010, Un ejemplo de llanura fluvio-deltaica influenciada por las mareas: el yacimiento de icnitas de Serrantes (Grupo Oncala, Berriasiense, Cuenca de Cameros, N. de España): Geogaceta, v. 49, p. 15-18.

ReIneck, H.E., And Singh, I.B., 1973, Depositional Sedimentary Environments: Berlin, Springer-Verlag, $439 \mathrm{p}$

ReITNER, J., 1993, Modern cryptic microbialite/metazoan facies from Lizard Island (Great Barrier Reef, Australia) formation and concepts: Facies, v. 29, p. 3-40.

Renaut, R.W., and Gierlowski-Kordesch, E.H., 2010, Lakes, in James, N.P., ed., Facies Models 4: St. John's, Newfoundland, Geological Association of Canada, p. $541-575$.

Renaut, R.W., And Long, P.R., 1989, Sedimentology of the saline lakes of the Cariboo Plateau, Interior British Columbia, Canada: Sedimentary Geology, v. 64, p. 239-264.

Riding, R., 2000, Microbial carbonates: the geological record of calcified bacterial-algal mats and biofilms: Sedimentology, v. 47 (Suppl. 1), p. 179-214.
Rouchy, J.M., Camoin, G., Casanova, J., and Deconinck, J.F., 1993, The central palaeo-Andean basin of Bolivia (Potosi area) during the Late Cretaceous and early Tertiary: reconstruction of ancient saline lakes using sedimentological, paleoecological and stable isotope records: Palaeogeography, Palaeoclimatology, Palaeoecology, v. 105 , p. 179-198.

Sabato, L., Bertini, A., Masini, F., Albianelli, A., Napoleone, G., and Pieri, P., 2005, The lower and middle Pleistocene geological record of the San Lorenzo lacustrine succession in the Sant'Arcangelo Basin (Southern Apennines, Italy): Quaternary International, v. 131, p. 59-69.

Salomon, J., 1982, El Cretácico inferior de Cameros-Castilla, in García, A., ed., El Cretácico de España: Madrid, Universidad Complutense de Madrid, p. 345-387.

Salvany, J.M., MuÑoz, A., AND PÉreZ, A., 1994, Nonmarine evaporitic sedimentation and associated diagenetic processes of the Southwestern margin of the Ebro Basin (lower Miocene), Spain: Journal of Sedimentary Research, v. 64, p. 190-203.

Sanz-Montero, M.E., Rodríguez-Aranda, J.P., and García del Cura, M.A., 2008, Dolomite-silica stromatolites in Miocene lacustrine deposits from the Duero Basin, Spain: the role of organotemplates in the precipitation of dolomite: Sedimentology, v. 55 , p. $729-750$

SChreiber, B.C., And Helman, M.L., 2005, Criteria for distinguishing primary evaporite features from deformation features in sulfate evaporites: Journal of Sedimentary Research, v. 75, p. 525-533.

Schreiber, B.C., Friedman, G.M., Decima, A., and Schreiber, E., 1976, Depositional environments of Upper Miocene (Messinian) evaporite deposits of the Sicilian Basin: Sedimentology, v. 23, p. 729-760.

Schubel, K.A., AND Lowenstein, T.K., 1997, Criteria for the recognition of shallowperennial-saline-lake halites based on recent sediments from the Qaidam Basin, western China: Journal of Sedimentary Research, v. 67, p. 74-87.

Schudack, M., and Schudack, U., 1989, Late Kimmeridigan to Berriasian paleogeography of the northwestern Iberian Ranges (Spain): Berliner Geowissenschaftliche Abhandlungen A, v. 106, p. 445-457.

Schudack, U., AND Schudack, M., 2009, Ostracod biostratigraphy in the Lower Cretaceous of the Iberian chain (eastern Spain): Journal of Iberian Geology, v. 35, p $141-168$.

Shteinman, B., Eckert, W., Kaganowsky, S., and Zohary, T., 1997, Seiche-induced resuspension in Lake Kinneret: a fluorescent tracer experiment: Water, Air and Soil Pollution, v. 99, p. 123-131

Sмоот, J.P., 1983, Depositional subenvironments in an arid closed basin; the Wilkins Peak Member of the Green River Formation (Eocene), Wyoming, U.S.A.: Sedimentology, v. 30, p. 801-827.

Sмоот, J.P., 1991, Sedimentary facies and depositional environments of early Mesozoic Newark Supergroup basins, eastern North America: Palaeogeography, Palaeoclimatology, Palaeoecology, v. 84, p. 369-423.

Smoot, J.P., And Lowenstein, T.K., 1991, Depositional environments of non-marine evaporites, in Melvin, J.L., ed., Evaporites, Petroleum and Mineral Resources: Amsterdam, Elsevier, Developments in Sedimentology 50, p. 189-347.

TANNER, P.W.G., 1998, Interstratal dewatering origin for polygonal patterns of sandfilled cracks: a case study from late Proterozoic metasediments of Islay, Scotland: Sedimentology, v. 45, p. 71-89.

Thomas, R.M., Meybeck, M., And Beim, A., 1996, Lakes, in Chapman, D., ed., Water Quality Assessments: A Guide to Use of Biota, Sediments and Water in Environmental Monitoring: London, Chapman \& Hall, p. 319-368.

WARREN, J.K., 1991, Sulfate dominated sea-marginal and platform evaporative settings: sabkhas and salinas, mudflats and salterns: Amsterdam, Elsevier, Developments in Sedimentology, v. 50, p. 69-187.

Warren, J.K., 2006, Evaporites: Sediments, Resources and Hydrocarbons: Berlin, Springer, $1035 \mathrm{p}$.

Weinberger, R., 2001, Evolution of polygonal patterns in stratified mud during desiccation: the role of flaw distribution and layer boundaries: Geological Society of America, Bulletin, v. 113, p. 20-31.

Zhang, X., AND Sha, J., 2012, Sedimentary laminations in the lacustrine Jianshangou Bed of the Yixian Formation at Sihetun, western Liaoning, China: Cretaceous Research, v. 36, p. 96-105.

ZuFfA, G.G., 1980, Hybrid arenites - their composition and classification: Journal of Sedimentary Petrology, v. 50, p. 21-29.

Received 9 June 2012; accepted 3 December 2012. 